\title{
Archaeological Survey of Upper Leon Creek Terraces, Bexar County, Texas
}

Cynthia L. Tennis

Center for Archaeological Research

Robert J. Hard

Department of Anthropology, University of Texas at San Antonio

Follow this and additional works at: https://scholarworks.sfasu.edu/ita

Part of the American Material Culture Commons, Archaeological Anthropology Commons, Environmental Studies Commons, Other American Studies Commons, Other Arts and Humanities Commons, Other History of Art, Architecture, and Archaeology Commons, and the United States History Commons

Tell us how this article helped you.

This Article is brought to you for free and open access by the Center for Regional Heritage Research at SFA ScholarWorks. It has been accepted for inclusion in Index of Texas Archaeology: Open Access Gray Literature from the Lone Star State by an authorized editor of SFA ScholarWorks. For more information, please contact cdsscholarworks@sfasu.edu. 


\section{Archaeological Survey of Upper Leon Creek Terraces, Bexar County, Texas}

Creative Commons License

(c) (i) (8)

This work is licensed under a Creative Commons Attribution-NonCommercial 4.0 International License 


\section{ARCHAEOLOGICAL SURVEY OF UPPER LEON CREEK TERRACES, BEXAR COUNTY, TEXAS}

Cynthia L. Tennis and Robert J. Hard

With contributions by

I. Waynne Cox and Lee C. Nordt

Robert J. Hard, Principal Investigator

${ }^{\circ}$ copyright

Center for Archaeological Research

The University of Texas at San Antonio

Archaeological Survey Report, No. 233 

The following information is provided in accordance with the General Rules of Practice and Procedure, Chapter 41.11 (Investigative Reports), Texas Antiquities Committee:

1. Type of investigation: Survey

2. Project name: Leon Creek Terrace Survey

3. County: Bexar

4. Principal investigator: Robert J. Hard

5. Name and location of sponsoring agency: U.S. Army Corps of Engineers, Fort Worth, Texas

6. Texas Antiquities Committee Permit No.: n/a

7. Published by the Center for Archaeological Research, The University of Texas at San Antonio, San Antonio, Texas 78249-0658, 1995

A list of publications offered by the Center for Archaeological Research is available. Call (210) 691-4378 or write to the Center for Archaeological Research, The University of Texas at San Antonio, 6900 N. Loop 1604 West, San Antonio, Texas 78249-0658. 



\begin{abstract}
In June and July 1994, the Center for Archaeological Research (CAR) of The University of Texas at San Antonio (UTSA) conducted an archaeological survey on a 147-acre tract of land along Leon Creek in northern San Antonio for Pape-Dawson Engineers. The archaeological work was needed for compliance with U.S. Army Corps of Engineers permit requirements before construction of a water storage facility.

Four archaeological sites (41BX40, 41BX47, 41BX48, and 41BX50) had been recorded within this area in 1970 by avocational archaeologists. Additionally, CAR staff members conducted a brief reconnaissance over a 60 -acre portion of the property in 1992.

Fieldwork consisted of pedestrian survey, 222 shovel tests, one 1-x-1-m test unit, backhoe trenches, plowing, and a geomorphological study by Lee

Nordt of Texas A\&M University. Evidence from this work suggests that two of the previously recorded sites, 41BX40 and 41BX47, are actually part of a single, largely intact, Early and Middle Archaic period site covering approximately 30 acres of the project area. The single site will retain the trinomial 41BX47. The site contains three components: a Middle Archaic one in the upper $50 \mathrm{~cm}$ of the northern part of the site; an Early Archaic component, also in the upper $50 \mathrm{~cm}$, found in the western part of the site; and a component of unknown age buried approximately $80-120 \mathrm{~cm}$ below the surface in the central part of the site. A transitional Archaic projectile point was found outside the boundaries of 41BX47. Further investigation of this site is recommended before construction of the water storage facility. A series of simulated sampling experiments was also conducted with the shovel test data to evaluate the effectiveness of different sampling designs.
\end{abstract}




\section{CONTENTS}

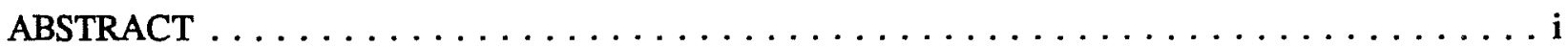

LIST OF FIGURES $\ldots \ldots \ldots \ldots \ldots \ldots \ldots \ldots \ldots \ldots \ldots \ldots \ldots \ldots \ldots \ldots \ldots$ iii

LIST OF TABLES $\ldots \ldots \ldots \ldots \ldots \ldots \ldots \ldots \ldots \ldots \ldots \ldots \ldots \ldots \ldots \ldots \ldots$ iii

ACKNOWLEDGMENTS $\ldots \ldots \ldots \ldots \ldots \ldots \ldots \ldots \ldots \ldots \ldots \ldots \ldots \ldots \ldots$ iv

INTRODUCTION $\ldots \ldots \ldots \ldots \ldots \ldots \ldots \ldots \ldots \ldots \ldots \ldots \ldots \ldots \ldots \ldots \ldots \ldots \ldots \ldots \ldots$

LOCATION AND NATURAL SETTING $\ldots \ldots \ldots \ldots \ldots \ldots \ldots \ldots \ldots \ldots \ldots \ldots \ldots$ HISTORIC BACKGROUND

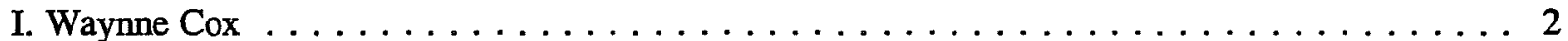

ARCHAEOLOGICAL BACKGROUND AND PREVIOUS INVESTIGATIONS $\ldots \ldots \ldots \ldots \ldots 3$

METHODS OF INVESTIGATION $\ldots \ldots \ldots \ldots \ldots \ldots \ldots \ldots \ldots \ldots \ldots \ldots \ldots$

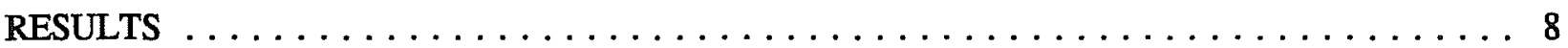

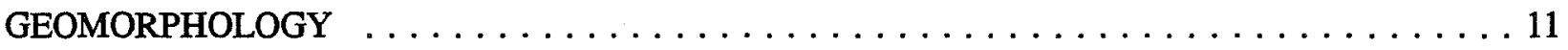

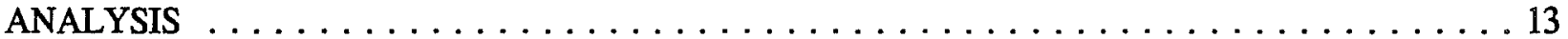

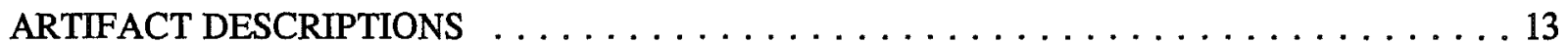

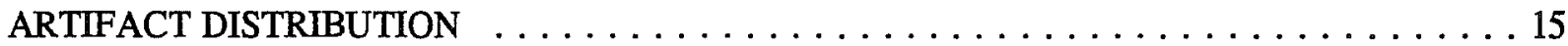

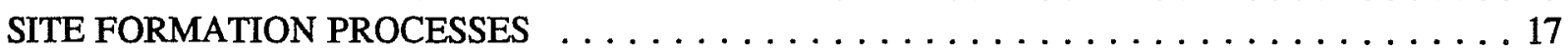

EVALUATING SHOVEL TEST SAMPLING INTERVALS $\ldots \ldots \ldots \ldots \ldots \ldots \ldots$

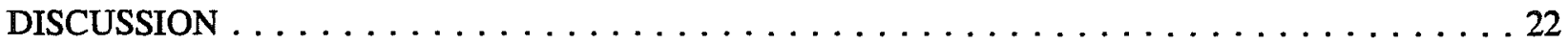

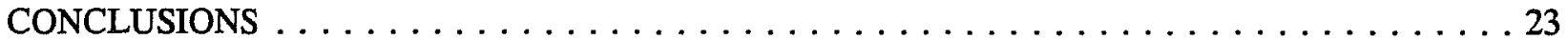

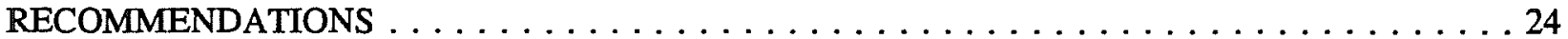

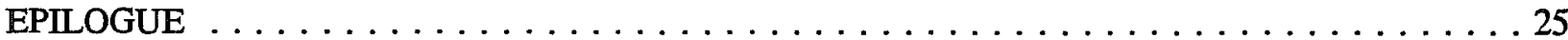

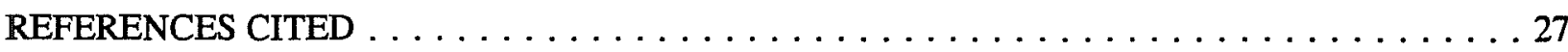

APPENDIX: GEOARCHAEOLOGY OF THE UPPER LEON CREEK BASIN

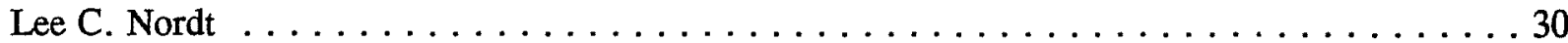




\section{FIGURES}

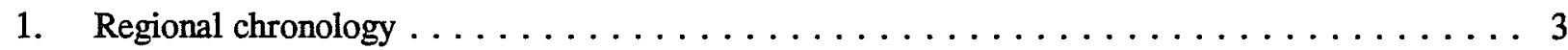

2. Sectors in the stratified survey design $\ldots \ldots \ldots \ldots \ldots \ldots \ldots \ldots \ldots \ldots \ldots \ldots \ldots \ldots \ldots \ldots$

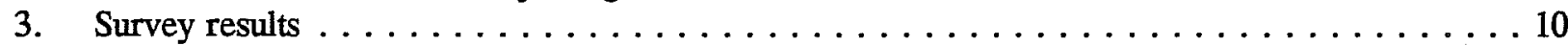

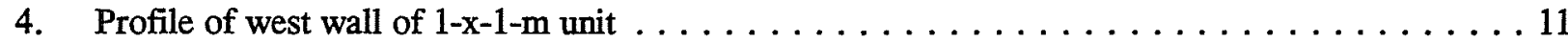

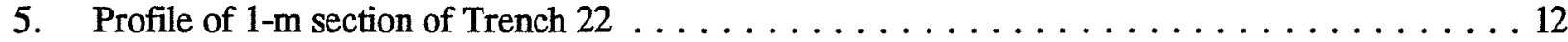

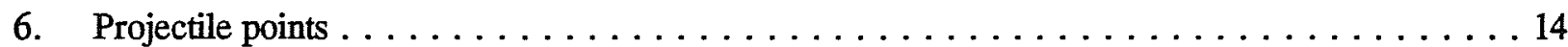

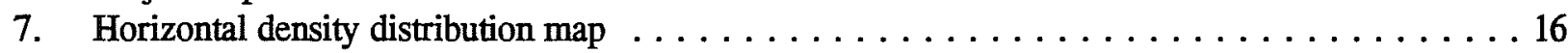

8. Gravel and artifact frequency comparison. $\ldots \ldots \ldots \ldots \ldots \ldots \ldots \ldots \ldots \ldots \ldots \ldots \ldots$

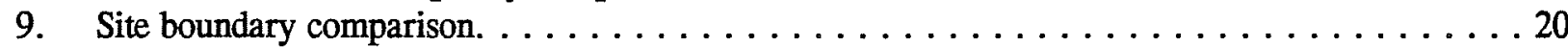

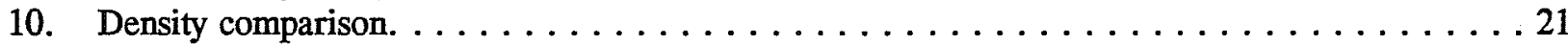

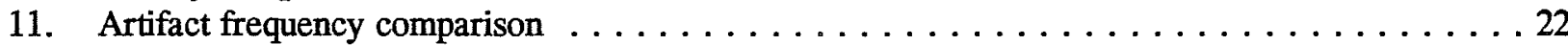

A-1. Geomorphic map of the Leon Creek study area $\ldots \ldots \ldots \ldots \ldots \ldots \ldots \ldots \ldots \ldots \ldots \ldots$

A-2. Schematic late Quaternary alluvial geologic cross-section of Leon Creek . . . . . . . . 32

\section{TABLES}

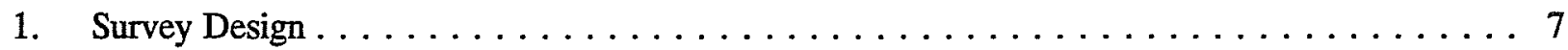

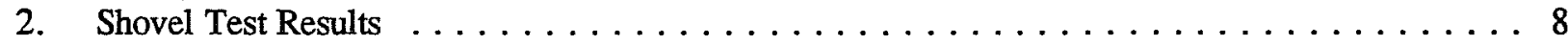

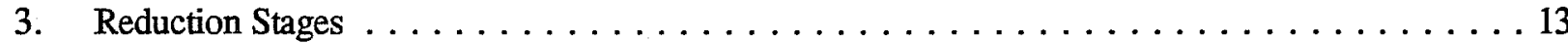

4. Vertical Distribution of Artifacts from Shovel Tests . . . . . . . . . . . . . . . 17

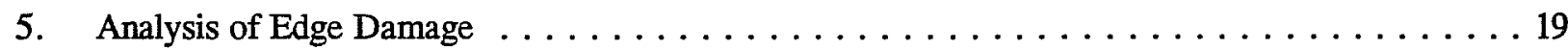




\section{ACKNOWLEDGMENTS}

We would like to acknowledge the project sponsor, Pape-Dawson Engineers; we enjoyed working with their staff, in particular John Rhinehart. Dixie Watkins was a superb liaison between Pape-Dawson and CAR. Jim Rector of Olmos Construction did a wonderful job of providing us with heavy equipment.

We would like to thank Lee Nordt, who provided many useful hours of discussion on the geomorphology of the study area; his expertise greatly enhanced the value of this project. Gene Meare of the Texas Archeological Research Laboratory in Austin also visited the site and provided added insights to the site's geological history.

Thanks also go to Kevin Gross, Waynne Cox, and Tom Davis for performing preliminary fieldwork. Cox also researched and wrote the Historic
Background section of this report. C. K. Chandler helped with point type identification. Points were illustrated by Robert Rector.

Britt Bousman, assistant director of CAR, offered his expertise in lithic analysis to assess the integrity of the deposits. Marcie Renner, our technical editor, as usual performed with speed and accuracy.

But most of all, the field crew-CAR staff archaeologists Jeff Durst, Florencio Delgado, and Tony Lyle, and UTSA student volunteers Joyce Lomas, Ed Johnson, Stewart MacLeod, and Rick Robinson-deserve the most praise. During a record-breaking string of 13 consecutive days with temperatures well over $100^{\circ}$, they completed 222 shovel tests and one excavation unit with precision, efficiency, and good humor. 


\section{INTRODUCTION}

In November 1993, Dixie Watkins of Dixie Watkins III and Associates contacted the Center for Archaeological Research (CAR) of The University of Texas at San Antonio (UTSA) on behalf of Pape-Dawson Engineers, requesting archaeological investigations at the 147-acre proposed site of a private water reservoir. While this project is privately owned and financed, the plans involve the modification of Leon Creek, a major drainage in north Bexar County. Such projects fall under the jurisdiction of the U.S. Army Corps of Engineers, which has permitting authority. Therefore, CAR's archaeological proposal and report were reviewed and approved by the U.S. Army Corps of Engineers in consultation with the Texas Historical Commission (State Historic Preservation Office).

Previous work in the project area included an avocational archaeological survey by Paul McGuff and Bill Fawcett in 1970, during which four archaeological sites were identified. A preliminary reconnaissance of portions of the project area was conducted by CAR personnel in 1992 (Uecker 1992). Both surveys indicated that archaeological material was present and further work would be needed. Because of the heavy equipment and earth movement needed for the construction of the water storage facility, a thorough survey was designed for the entire project area. This program included survey in a plowed area, survey with shovel tests at 20- and 30-m intervals, backhoe trenches, and one $1-\mathrm{x}-1-\mathrm{m}$ excavation unit.

Robert J. Hard served as principal investigator and Cynthia Tennis as project archaeologist. Most of the fieldwork was conducted during the last two weeks of July 1994, by a crew of four CAR staff archaeologists and four UTSA anthropology students. Altogether 222 shovel tests, 27 backhoe trenches, and one 1-x-1-m unit were dug. These activities resulted in recovery of 730 chert artifacts, including six projectile points. Through these tests and the surface examination of the plowed area, new site boundaries were established, combining $41 \mathrm{BX} 40$ and $41 \mathrm{BX} 47$ into one large $(400 \times 520 \mathrm{~m})$ site, $41 \mathrm{BX} 47$. Three components are present, including a Middle Archaic component containing two Nolan points; an Early Archaic component containing one Gower and two Uvalde points; and an Early Archaic or earlier buried component from which only flakes were recovered. All research notes, field and laboratory records, and artifacts are curated at the CAR laboratory.

\section{LOCATION AND NATURAL SETTING}

The 147-acre project area is located in northwest San Antonio. The area is situated on an inside meander of Leon Creek, one of several prominent streams draining the Edwards Plateau to the north. Major drainages in the area include the Guadalupe River to the north, the San Antonio River to the south, and the Medina River to the south and southwest. Leon Creek empties into the latter south of downtown San Antonio.

The land surface in the project area slopes gently up from the creek, rising only eight feet from the modern floodplain (T0) to the irregularly shaped first (T1a) and second (T1b) terraces in the southeastern section of the property (see Appendix). These terraces were created through repeated episodes of cutting and overbank depositing of the creek as it shifted location through time. Vegetation consists of large native oak and hackberry trees along the edge of the creek and mesquite and persimmon on the terraces.

Soils in the survey area are a combination of Patrick soils $(\mathrm{PaB})$, Lewisville silty clay (LvB), and Venus loam (VaB) (Taylor et al. 1991). Patrick soils, which make up slightly more than half the soil within the study area, consist of shallow clay loams, gravelly clay loams, or silty clays which occur as level to gently sloping terraces along streams draining the limestone prairies to the north. These soils generally have deep beds of carbonate-coated, waterworn, limestone gravel within three feet of the surface. The Lewisville silty clay soils are dark alluvial 
soils that generally separate level terraces from upland soils. These soils are moderately deep, ranging from 36-60 inches and are often underlain by deep beds of water-rounded limestone gravels. Venus loam makes up only a small portion of the soil in the project area and is described as moderately dark, deep loam or clay loam soils occupying narrow terraces along major watercourses. Just to the east of the survey area is a section of Crawford and Bexar stony soils, a clay containing of 10-40 percent chert (Taylor et al. 1991).

\section{HISTORIC BACKGROUND}

\section{Waynne Cox}

The project property constitutes the central portion of a grant of a league of land allowed to Anselmo Pru by virtue of his having been proven to be a resident of Texas prior to the Declaration of Independence, March 2, 1836 (Garry Mauro, General Land Office Information Sheet, Stephen F. Austin Building, Austin, Texas). This grant was transferred to William Steele and Ludovic Colquhoun, who selected the land on Leon Creek and had it surveyed and recorded in February 1838 (Bexar County Survey Book [BCSB], Office of the County Clerk, Bexar County Courthouse, San Antonio, Texas, A1:Survey 20). This survey comprised a league and labor of land-over 4,600 acres-and was watered by Leon Creek which ran through the entire property. Steele and Colquhoun were land promoters and speculators during the early days of the Republic period and dealt extensively with property throughout Texas.

Colquhoun and his wife, Francis, while residing in New Orleans, transferred the property to Charles Cocke of Albemarle County, Virginia, for $\$ 3,000$ in January 1847 (Bexar County Deed Records [BCDR], Office of the County Clerk, Bexar County Courthouse, San Antonio, Texas, Volume E2:23). In 1851 Charles Cocke transferred the upper one-third of the grant-1,476 acres-to Joseph B. Anderson of Amelia County, Virginia (BCDR, K1:450). In 1874 James L. Anderson, executor of the estate of "the deceased Joseph
Anderson," sold the tract to John Moos for "\$1500 Gold Dollars" (BCDR, 2:15). This tract was apparently used solely for ranching and agricultural purposes, for there are no indications of structures having been constructed on the property during the Moos family occupation.

John (Johann) Moos, born November 19, 1825, was a native of Offdillen-Nassau, Germany. At age 20 he immigrated with his parents, Johannes and Elisa Moos, and three brothers to Texas as members of the Adelsverein Society under the direction of Prince Solms-Braunfels. Sailing aboard the Semiramis, they departed the port of Bremen on August 18, 1845, and arrived on the Texas coast on October 22, 1845 (Mr. and Mrs. J. L. Stone, History of the Moos Homestead [HMH], Kay Hart Collection, San Antonio clipping files, Library of the Daughters of the Republic of Texas, The Alamo, San Antonio, Texas, 1964:1). The Moos family was among the first to settle in the Fisher and Miller Colony near the San Saba River (BCSB, G6:Surveys 165, 180, 181).

After the death of his father and brother Jacob in 1846 during a cholera epidemic, John and others of the colony decided to locate in areas south of Fredericksburg. John selected a tract of land along the "Emigrant" or Fredericksburg Road on the waters of Leon Creek (BCDR, S1:218). Although the information in support of the nomination of the property as a Texas Historic Landmark states that Moos established his homestead on Leon Creek and constructed his homestead there in 1850-1851, current research reveals that Moos received title to his first property in Bexar County in 1860 (HMH, 1964:1; BCDR, S1:218). In fact, the recognized homestead site is actually located on Survey 21 , which was acquired by his wife following the death of John Moos (BCDR, 35:73).

John Moos married Anna Rosina Aden-born July 20, 1836, in Hesse, Germany-who had also immigrated to Texas as a member of the SolmsBraunfels Colony (HMH, 1964:1; United States Census [USC], Texas, Bexar County, 1880). They had seven children born between 1857 and 1879 (USC, Bexar County, 1880). After John's death in 1879, Rosina continued to maintain the ranch and 
added property until, by 1890 , it totaled over 1,917 acres (BCDR, 33:636, 35:73, 51:85, 91:113). The family continued the ranching and farming operation until July 1951 when the heirs sold the entire tract to developers George W. Delvan, Sr., and Robert Roy Baines (BCDR, 3057:512). The property was probably leased, with ranching and farming continued as before. In 1994 Delvan transferred the property to the Texas Industrial Laundries Profit Sharing Trust, listed by the Bexar County Tax Office as the current property holders (BCDR, 4842:1318).

\section{ARCHAEOLOGICAL BACKGROUND AND PREVIOUS INVESTIGATIONS}

Although more archaeological sites have been recorded and excavated in central Texas than in any other part of the state, the cultural history and chronology of the area are still unclear and remain topics of investigation and debate (Black 1989; Collins et al. 1990; Johnson 1986, 1991; Johnson and Goode 1994; Potter et al. 1995; Prewitt 1981, 1985). Researchers have expressed different views on the chronological divisions and associated terminology for the major time periods of central and south Texas prehistory. This confusion arises, at least in part, from the very nature of the sites being investigated, and the long period of yetundifferentiated hunter-gatherer adaptations they represent. The outline of the region's cultural history given here is based on Black's (1989) synthesis, but will be limited to the generally agreed upon description of the three major periods: Paleoindian, Archaic, and Late Prehistoric (Figure 1).

The Paleoindian period (ca. 11,000-8000 B.P.) has been described as a time when small, highly mobile bands of hunters exploited herds of now-extinct large mammals at the end of the Pleistocene. Recent studies being done at the WilsonLeonard site, Burger Bluff site, and 41BX52 promise to increase our understanding of the role played by small game and plant foods in the subsistence strategies of this period.

The Archaic period (ca. $8000-1150$ B.P.) encompassed a 7,000-year period of hunting-andgathering adaptations following the Pleistocene. In the early part of the Archaic period population densities were low, and small, highly mobile bands exploited a wide variety of resources. Black (1989) suggests that sites were concentrated along the Balcones Escarpment because of greater water availability. During the middle part of the Archaic period, burned-rock midden features were widespread, suggesting the formation of a more specialized economy and increased population density. By the later part of the Archaic period, the frequency of burned-rock midden features declined

\begin{tabular}{|c|c|c|c|}
\hline $\begin{array}{c}\text { Calendar } \\
\text { Years }\end{array}$ & $\begin{array}{c}\text { Geologic } \\
\text { Epoch }\end{array}$ & Regional Period & Years B.P. \\
\hline-1950 & \multirow{5}{*}{ 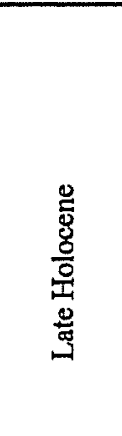 } & Historic & \multirow{5}{*}{$1000-$} \\
\hline-1000 & & Late Prehistoric & \\
\hline $\begin{array}{l}\text { A.D. } \\
-0 \\
\text { B.C. }\end{array}$ & & Late Archaic & \\
\hline-1000 & & Middle Archaic & \\
\hline-2000 & & & \\
\hline-3000 & & & 5000 \\
\hline-4000 & 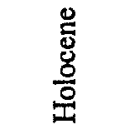 & Early Archaic & $6000-$ \\
\hline-5000 & $\frac{0}{\frac{0}{0}}$ & & 7000 \\
\hline-6000 & & & $8000-1$ \\
\hline & $\begin{array}{l}\mathscr{E} \\
\stackrel{\Xi}{0}\end{array}$ & & \\
\hline-8000 & 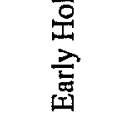 & Paleoindian & 10000 \\
\hline-9000 & & & 11000 \\
\hline
\end{tabular}

Figure 1. Regional chronology. 
and bison bones increased, suggesting another shift in subsistence strategies. Several large cemetery sites may indicate increased territorialism and the distribution of certain grave goods may reflect the existence of trade networks.

During the Late Prehistoric period (ca. 1150-350 B.P.) hunters and gatherers adopted the bow and arrow and apparently made greater use of protected rockshelter locations. Population density may have declined and burials with embedded projectile points signal increased intergroup conflict. Toward the end of the Late Prehistoric period, shifts in lithic technology and subsistence and the introduction of ceramics indicate an evolving adaptation that is not well understood. Some investigators suggest that a migration into the area or increased interactions with peoples from outside central Texas occurred (Black 1989).

Sites in Bexar County contain cultural remnants spanning the entire prehistoric human occupation in central Texas, including Paleoindian components from the St. Mary's Hall site (Hester 1978, 1991) and Olmos Dam (Stothert 1989); Archaic components from the Panther Springs Creek site (Black and McGraw 1985), the Richard Beene site (Thoms 1992), and the Wurzbach Road Project (Potter et al. 1995); and Late Prehistoric components from 41BX274 (McGraw and Hindes 1987).

A search of records in the CAR files revealed that 15 sites, including the four located on the property under study, have been recorded within a threekilometer radius of the current project. These sites are all located along Leon Creek or one of its smaller tributaries. Except for 41BX52, a Paleoindian site excavated by the Texas Highway Department which is being reanalyzed by Michael Collins of the Texas Archeological Research Lab (TARL) in Austin, none of these sites has been further investigated. However, from a review of the site forms on file at CAR, the Leon Creek drainage was clearly utilized by prehistoric people of the region for many millennia.
A summary of the information on the data forms for the four sites recorded by Paul McGuff and Bill Fawcett within the project area follows.

$41 \mathrm{BX} 40$ is described as a possibly late Paleoindian open campsite, $500 \times 300 \mathrm{ft}$ in size, on a floodplain below a dammed portion of Leon Creek. All artifacts were collected. Previous artifact collecting and bulldozer disturbances are mentioned.

41BX47 is described as a large, open campsite, $800 \times 400 \mathrm{ft}$ in size, on a river terrace. Cultural material includes projectile points, clusters of burned or fire-cracked rock, and other artifacts. The cultural affiliation is listed as Archaic. Disturbances listed include a trash pit and bulldozing.

41BX48 is described as a two-foot wide remnant of topsoil on a peninsula in the creek. The western edge was eroded down to gravel and the east side destroyed by a road and quarry. McGuff and Fawcett collected several items including one projectile point which they drew and identified as a Meserve or Plainview type. Without the artifact, it is difficult to verify this identification.

41BX50 is described as a site of unknown dimensions on a terrace or floodplain. One biface and one possible broken projectile point were noted. 


\section{METHODS OF INVESTIGATION}

Before defining the scope of work for this project, existing site records, topographic maps, and a series of aerial photographs were examined, and two visits were made to the 147 -acre project area. Four sites (41BX40, 41BX47, 41BX48, and 41BX50) had previously been recorded along Leon Creek within the project area. Additionally, topographic maps revealed the existence of terraces, with a potential for buried sites, along the creek. Evidence of past quarrying activities also featured on the maps was visible in more detail in the aerial photographs, as were several areas of undetermined disturbance and an area previously under cultivation.

The project area was divided into six study areasA, B, C, D, P1, and P2 (Figure 2)-based on survey methods tailored for the locations of known sites as well as for the four different surface conditions identified (Table 1). Surface inspections during the 1992 area investigation (Uecker 1992) and two more-recent visits to the project area indicated that no surface remnants of the recorded sites remained. However, one shovel test near 41BX47 produced lithic debitage and one Nolan point.

Shovel test procedures were established and reviewed with the crew before fieldwork began. Shovel tests were an average of $30 \mathrm{~cm}$ in diameter and were dug, in 10-cm levels, to a depth of $50 \mathrm{~cm}$ where possible. Dirt from each level was screened through 1/4-inch hardware cloth and all artifacts from the shovel tests were collected, bagged, and recorded by area, shovel test number, and depth. Forms were completed for each test, recording artifacts, soil description, gravel size, and percentage of gravel per level.

At the request of the contractor, nine shovel tests, referred to in this report as SL (sewer line) 1-9, were excavated along the proposed route of a sewer outfall trench scheduled for excavation early in the project. However, when three of these tests in the general area of 41BX47 revealed lithic debitage, trenching was delayed until the completion of the entire survey.

\section{AREA P1}

Aerial photographs taken in 1966 show that the 40acre area in the south central section of the project area (P1), now sparsely covered by 3 - to 4-inch diameter mesquite, was then under cultivation. Subsequent photographs from 1973 and 1986 indicate that, other than these farming activities, no modifications had been made to the land included in this study. Prior plowing could have caused some upward and lateral movement of larger artifacts (Schiffer 1987) in the upper 4-6 inches of soil in the field, but should not have disturbed cultural material below this depth. Therefore, the survey strategy for this portion of the area involved a systematic walkover, with crew members spaced at 20-m intervals, after the acreage had been cleared and replowed to expose underlying deposits.

The clearing was accomplished by a 140G Caterpillar Maintainer with a 12-ft canted, underslung blade and four ripper claws on the back. All brush and trees were cleared with the blade without disturbing the subsurface root systems. A 544C Cat front-end loader with a one-yard bucket set just above ground level was used to move the cleared brush into piles. The ripper claws on the $140 \mathrm{G}$ were then used to break the ground surface, creating furrows $30 \mathrm{~cm}$ apart and $15 \mathrm{~cm}$ deep. A second pass was made in most areas of the field, narrowing the distance between furrows to approximately $15 \mathrm{~cm}$ for maximum visibility. Clearing and ground breaking activities were monitored by a CAR archaeologist.

Transects were walked at 20-m intervals; locations of chert debitage were marked with flagging tape; and diagnostics were collected, assigned unique item (UI) numbers, and plotted on the field map. Eight shovel tests were excavated along the southeast edge of the field in the general area of 41BX50 where UI 1 (an Ensor-like point) was found. Five backhoe trenches were placed in the plowed field for analysis by the geomorphologist. 
This page has been

redacted because it

contains restricted

information. 
Table 1. Survey Design

\begin{tabular}{|c|c|l||}
\hline Area & $\begin{array}{c}\text { Approximate } \\
\text { Acreage }\end{array}$ & \multicolumn{1}{c|}{ Testing Method } \\
\hline Known Sites & 13 & Walkover w/ shovel tests at $20 \mathrm{~m}$ \\
\hline A & 10 & $\begin{array}{l}\text { Walkover w/ shovel tests at } 30 \mathrm{~m} \text {, backhoe trenches at } \\
\text { creek }\end{array}$ \\
\hline B & 6 & Brief inspection, backhoe trenches \\
\hline C & 13 & Walkover w/ shovel tests at $30 \mathrm{~m}$ and $20 \mathrm{~m}$ \\
\hline D & 17 & $\begin{array}{l}\text { Walkover w/ shovel tests at 30 m, backhoe trenches at } \\
\text { creek }\end{array}$ \\
\hline P1 & 40 & Walkover at 20 m after area cleared and replowed \\
\hline P2 & 2 & $\begin{array}{l}\text { Walkover w/ shovel tests at 30 m, backhoe trenches at } \\
\text { creek }\end{array}$ \\
\hline Disturbed & 59 & $\begin{array}{l}\text { No survey, area heavily disturbed or not impacted by } \\
\text { construction }\end{array}$ \\
\hline
\end{tabular}

\section{AREAS A AND D}

Transect lines were walked and shovel tests excavated at $30-\mathrm{m}$ intervals in Areas A and D. Twenty-nine shovel tests were executed in Area A, 11 of which were in the general area of $41 B X 40$. Twenty-two shovel tests were excavated in Area D. Two backhoe trenches were placed in Area A, one at the edge of the floodplain in the southwest corner of the property, the other on the first terrace within the estimated boundaries of 41BX40. Two trenches were also dug in Area D at the edge of Leon Creek.

\section{AREAS C AND P2}

The original survey plan called for survey and shovel tests at 30-m intervals in Areas C and P2. However, because of the proximity of Area $\mathrm{C}$ to the lithic scatter in the plowed field and the appearance of chert debitage in the first few shovel tests in Area C, intervals were adjusted to $20 \mathrm{~m}$. Undisturbed portions of $\mathrm{P} 2$ thought to contain $41 \mathrm{BX} 47$ were also tested at $20-\mathrm{m}$ intervals.
One hundred fourteen shovel tests were executed in Area C, with an additional 21 in Area P2. One $1-\mathrm{x}-1-\mathrm{m}$ unit was excavated to a depth of $60 \mathrm{~cm}$ in an area of heavy lithic concentration in Area C. Five backhoe trenches were excavated in areas of artifact concentration in Area $\mathrm{C}$ and one was placed perpendicular to the creek in Area P2.

\section{AREA B}

Shovel tests were not scheduled for Area B, as no construction was planned for this part of the property and it appeared highly disturbed on our initial visit. However, because part of this area had been designated as 41BX50 during the 1970 survey, a brief inspection was conducted and two backhoe trenches were dug to look for evidence of buried material. 


\section{ADDITIONAL WORK IN AREA P1}

After reviewing the initial findings from the survey of the entire project area, additional investigation not included in the original scope of work was done in the Area P1. To establish a connection between the subsurface finds in Area $C$ and the surface scatter in the plowed field, 16 shovel tests were excavated along the northern edge of the field, on a line and $20 \mathrm{~m}$ south of each transect in Area C. Using the flag markers from the original inspection of the field, two areas of lithic concentration were identified on the northwest side of the field. The approximate extent and location of these concentrations were plotted on the field map and a series of shovel tests, five in each concentration, was dug to determine depth of the deposit. Ten shovel tests were placed at $30-\mathrm{m}$ intervals across the lithic scatter in the northern portion of $\mathrm{P} 1$. Based on recommendations from the geomorphologist, an additional nine backhoe trenches were dug in the Tlb terrace to look for deeply buried sites.

\section{RESULTS}

Areas $A$ and D were surveyed and shovel tests were dug at $30-\mathrm{m}$ intervals along the survey transects except in areas previously impacted by quarrying or dumping activities. Of the 42 tests dug, only three produced lithic materials, all from within the top $30 \mathrm{~cm}$ of soil.
Along the southeast edge of the plowed field (P1), one biface and one diagnostic point were observed during survey. As these were found in what was thought to be the general area of 41BX50, a thorough search was made of the surrounding area and eight shovel tests were placed within a $20-\mathrm{m}$ radius of the finds. No further artifacts were noted on the surface and only one chert flake was recovered from the shovel tests, at a depth of $50 \mathrm{~cm}$ below the surface. The diagnostic (UI 1), which shows signs of retouch and some breakage, is thought to be Ensor-like, a point type associated with the transition between the Late Archaic and Late Prehistoric periods.

The survey of the north and west sections of the plowed area (P1) revealed a widely dispersed, lowdensity artifact scatter, approximately $530 \mathrm{~m}$ long and $100 \mathrm{~m}$ wide. Included in this scatter were numerous biface fragments and three diagnostic projectile points, one Gower (UI 2) and two Uvalde (UI 3 and UI 4); both types are associated with the Early Archaic period.

Area $\mathrm{C}$ was surveyed at $20-\mathrm{m}$ intervals to identify the horizontal and vertical extent of a new site encountered during our November 1993 site inspection, when a Nolan point (UI 8) was excavated from a preliminary shovel test. Fortyeight of the 116 shovel tests in this area revealed subsurface artifacts to a depth of at least $50 \mathrm{~cm}$ below the surface over an area $280 \mathrm{~m}$ E/W by $140 \mathrm{~m}$ N/S (Table 2). The horizontal distribution of the

Table 2. Shovel Test Results

\begin{tabular}{||c|c|c|c|}
\hline Area & \# Shovel Tests & \# Productive & \# Artifacts \\
\hline SL (Sewer line) & 9 & 3 & 6 \\
\hline A & 22 & 4 & 5 \\
\hline C & 116 & 48 & 235 \\
\hline D & 20 & 0 & 0 \\
\hline P1 & 45 & 19 & 70 \\
\hline P2 & 10 & 1 & 1 \\
\hline C & $(1-x-1-m$ unit) & (yes) & 368 \\
\hline TOTAL & $\mathbf{2 2 2 + 1}$ & $\mathbf{7 5 + 1}$ & $\mathbf{6 8 5 . 0 0}$ \\
\hline
\end{tabular}


artifacts suggested at least two areas of concentration: one to the west of the borrow pit, the other to the east. A single 1-x-1-m unit, excavated to a depth of $60 \mathrm{~cm}$ below the surface, was excavated in the western concentration. Three hundred sixtyeight chert artifacts, including a broken Nolan point (UI 6), were recovered. The two Nolan points from this area may be placed chronologically in either the Early Archaic (Turner and Hester 1993) or the Middle Archaic (Johnson and Goode 1994); we are using the latter.

Subsequently, 41 shovel tests were placed along the northern edge of the P1 area to verify the depth of the archaeological deposits and to determine if a connection exists between the Archaic subsurface material in Area $\mathrm{C}$ and the Early Archaic surface scatter in Area P1. Nineteen of these shovel tests produced lithic artifacts from depths of up to $50 \mathrm{~cm}$ below the surface, confirming that the two survey areas were actually part of one large site covering approximately $150,000 \mathrm{~m}^{2}$ (Figure 3 ).

The four archaeological sites (41BX40, 41BX47, 41BX48, and 41BX50) recorded in 1970 were investigated as well. No evidence could be found of 41BX48, which had already eroded to a twofoot wide strip between the creek and the quarry when it was originally recorded. On the extreme eastern edge of the plowed field (P1) in the area of 41BX50, one diagnostic point and one biface were found on the surface. Shovel tests in the immediate area of these surface finds contained one biface from a depth of $50 \mathrm{~cm}$ below the surface. However, backhoe trenches revealed that most of the area east of the plowed field has been thoroughly disturbed to a depth over $150 \mathrm{~cm}$. Apparently little or no intact deposits remain in these two areas.

No surface remains were found of $41 \mathrm{BX} 47$, originally recorded as an $800-\mathrm{x}-400$-ft site along the dammed portion of the creek in our Area P2. Shovel tests produced one lithic artifact from a depth of $20-30 \mathrm{~cm}$ below the surface, but the presence of modern glass at $30 \mathrm{~cm}$ in one of these tests and the mixed deposits visible in the backhoe trench suggest this area has also been highly disturbed. Similarly, no surface indications remain of site $41 B X 40$, in the northern portion of our Area A. Again, previous activities disturbed a large portion of this area, but shovel tests did reveal subsurface deposits down to $30 \mathrm{~cm}$ below the surface.

The proximity of these two sites, $41 \mathrm{BX} 40$ and 41BX47, to the surface and subsurface artifacts found in Areas $C$ and $P 1$ suggests that our latest findings are actually extensions of these previously recorded sites that had gone undetected during the original survey. Apparently what exists is one largely intact site covering an area roughly $400 \mathrm{~m}$ $\mathrm{N} / \mathrm{S}$ by $520 \mathrm{~m} \mathrm{E} / \mathrm{W}$. The site seems to contain three spatially and temporally separate components: one associated with the surface-to-50-cm deposit in Area $\mathrm{C}$ which contains diagnostics from the Middle Archaic; one in the western section of P1 associated with the early and late portions of the Early Archaic; and a third, more deeply buried, component in the northeastern section of $\mathrm{P} 1$. The last, possibly older cultural deposit, was discovered by finding an artifact-bearing zone from $80-120 \mathrm{~cm}$ below surface in four of the additional backhoe trenches (T18, 19, 21, and 22) excavated in P1. Numerous flakes from each trench were recovered both in situ and during backhoe operation from this particular zone. The horizontal extent of this earlier component is unknown. An additional point, dating to the transition from the Archaic period to the Late Prehistoric period, was found outside the boundaries of 41BX47.

Because of the buried nature of the deposit and the small amount of excavation conducted in this phase of work, no features were identified and no bone or botanical remains were recovered. However, a scatter of fire-cracked rock was noted in Area C and one possible concentration of burned rock was seen in the backdirt from Trench T2 also in Area C. 
This page has been

redacted because it

contains restricted

information. 


\section{GEOMORPHOLOGY}

The geomorphology of the project area is fully described by Lee Nordt in the Appendix. The study area includes part of the modern Leon Creek floodplain (T0) and a subdivided first terrace (T1a and T1b). Up to $60 \mathrm{~cm}$ of T0 sediments overlap the margin of the Tla terrace in places. Nordt (Appendix) has assigned the T0 sediments to an age range of 4000 B.P. to present, but they are confined to the modern channel or in sharp meander bends. The two Nolan points were recovered from within this fine-grained sediment assemblage that contacts the gravel deposits at a depth of $60 \mathrm{~cm}$ below the surface in the west wall of the 1-x-1-m unit (Figure 4).
The $\mathrm{T} 1 \mathrm{a} / \mathrm{T} 1 \mathrm{~b}$ alluvial terrace was formed by the repeated cutting and overbank depositing by the creek as it shifted locations through time. Whether these terraces are facies of a single stratigraphic unit that formed between $8000-5000$ B.P., or the T1b terrace is older and formed during the Early Holocene is unclear at this time. The sediment assemblage in the Tla terrace contains a high percentage of large gravels below a depth of $50-100 \mathrm{~cm}$, suggesting a flood surge of a magnitude high enough to have disturbed in situ cultural context. However, above $50 \mathrm{~cm}$ gravel content and size decreases and the gravels are supported in a fine-grained matrix, increasing the possibilities of in situ cultural deposits in this upper zone that contained Early Archaic Gower and Uvalde projectile points.

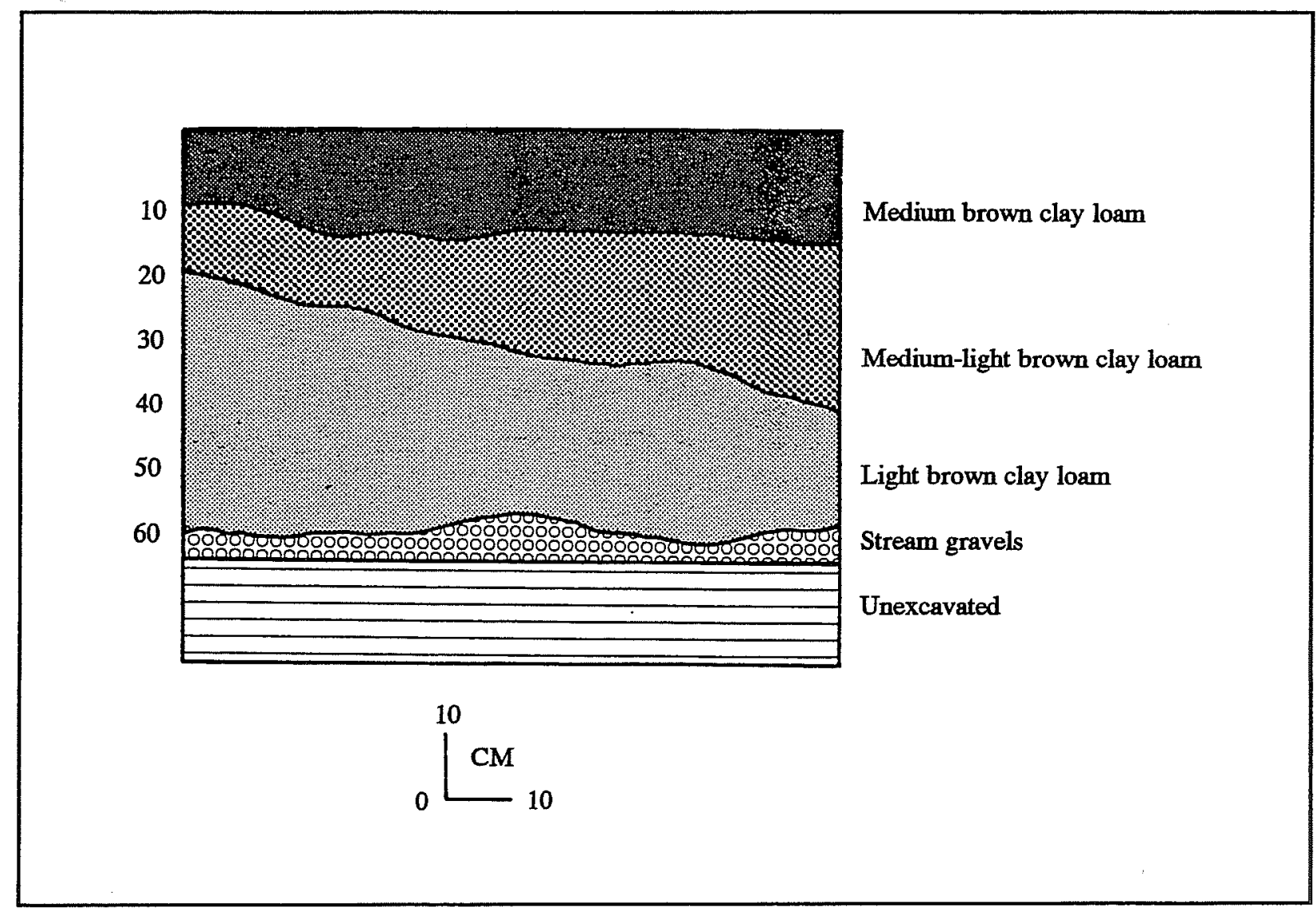

Figure 4. Profile of west wall of 1-x-1-m unit. 
Trench 22 in the $\mathrm{T} 1 \mathrm{~b}$ terrace does not contain stream gravels at 50-60 cm (Figure 5); instead, sediments grade from an $A$ horizon of medium brown, silty clay loams from $0-40 \mathrm{~cm}$, to a lighter brown, clay loam with secondary calcium carbonate filaments from $40-80 \mathrm{~cm}$. From $80-110 \mathrm{~cm}$ the sediment is light red brown, carbonate-streaked, blocky clay loam. This is the layer that contains cultural material and many Rabdotus shells. Below this deposit, the sediment becomes a light beige, silty clay loam with few calcium carbonate inclusions, grading to a fine-grained, compact, light beige clay that continues to $240 \mathrm{~cm}$ below the surface. Pea- to golfball-sized unconsolidated gravels ( 70 percent) with a yellowish tan sandy matrix make up the next layer, followed by a layer of light $\tan$ sand with no gravels. The bottom three levels consist of a light reddish tan sand lens between two layers of consolidated gravels. Pea- to golfball-sized gravels make up 98 percent of the upper layer, while the bottom layer has fewer ( 45 percent), mostly marble-sized gravels in a reddish sand matrix. The high calcium carbonate content and the lack of sharp contacts between the layers above these bottom two consolidated gravel layers indicate that the upper 2.8-3 $\mathrm{m}$ in the trench represents an intact alluvial unit, with high potential for preservation of materials in an archaeological context. Depending on the chronological interpretations, this archaeological component could be either Early Archaic or Paleoindian.

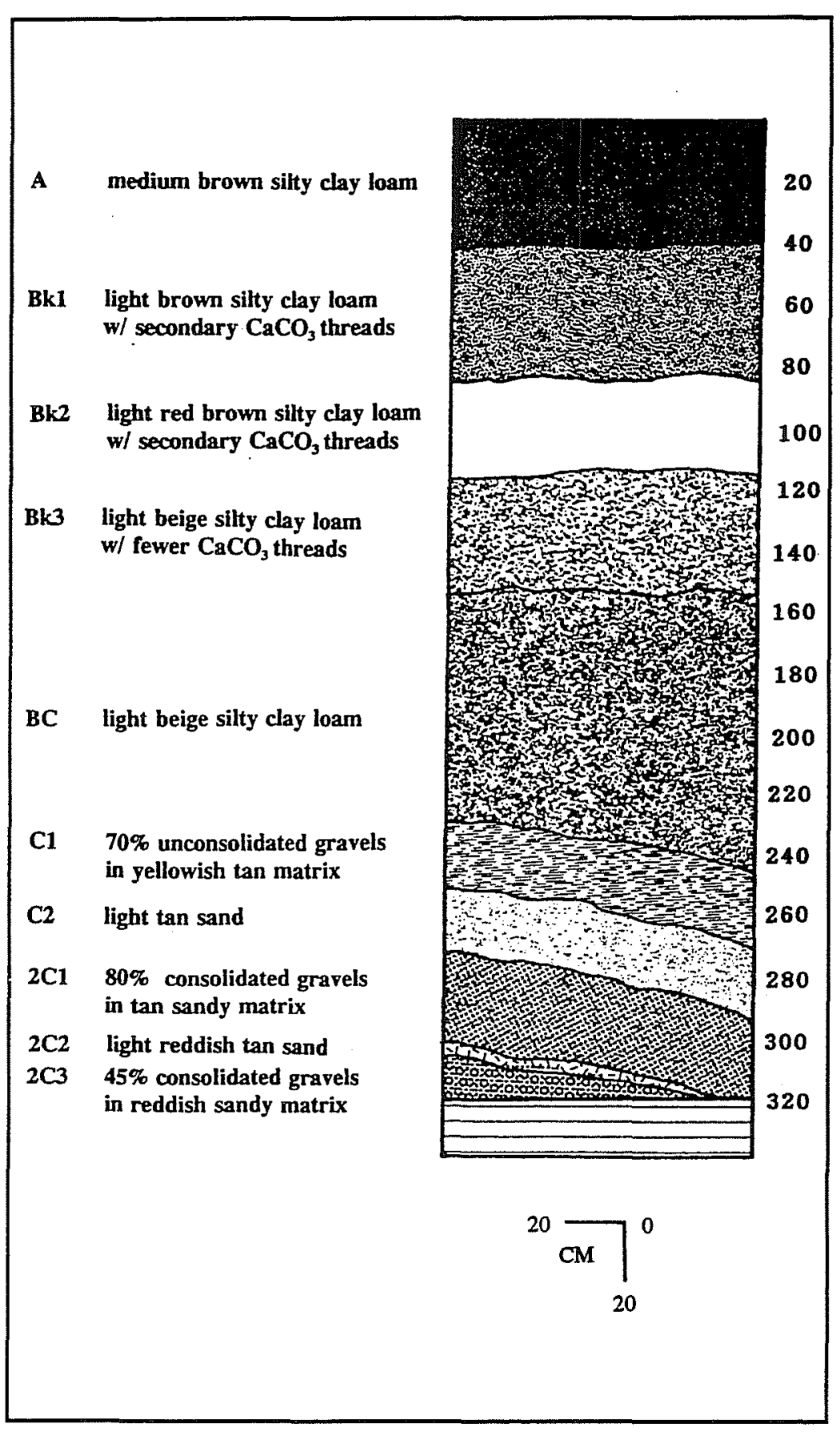

Figure 5. Profile of 1-m section of Trench 22. From Nordt (Appendix). 


\section{ANALYSIS}

\section{ARTIFACT DESCRIPTIONS}

Lithic materials constitute all artifacts recovered from surface collection and shovel tests in the project area. The 730 lithics include remnants from all stages of stone tool production, from exhausted cores to finished product (Table 3). These were divided into six categories based on the following characteristics:

Primary flake - 100 percent cortex on dorsal face.

Secondary flake - between 1-99 percent cortex on dorsal face.

Tertiary flake -0 percent cortex on dorsal face.

Core - parent material from which flakes have been detached.

Tools and Points - retouched flakes, bifaces, and points.

Chips and chunks - debitage not exhibiting striking platforms or bulbs of percussion.
Points and Other Bifaces

Twenty bifaces and biface fragments were recovered during testing. Included in this category are six diagnostic points, four distal point fragments, one alternately beveled medial point fragment, one alternately beveled preform, and eight biface and biface fragments. Five of the points were recovered from the area designated as 41BX47: three from the surface in the plowed area, two from excavated test units. These points appear to be types associated with the Early and Middle Archaic occupations in central Texas. The sixth point was found on the surface in the area of 41BX50. Because of retouch and breakage, possibly recent, the identification of this point is problematic. These diagnostic points were given Unique Item (UI) numbers in the field, and will be described here using information and chronology from Johnson and Goode (1994), Potter et al. (1995), and Turner and Hester (1993).

\section{Early Archaic}

Gower point, Unique Item 2 (Figure 6a).

This point was recovered from the surface in the north central section of $\mathrm{P} 1$ on the T1a terrace. The tip and one barb are broken. It is made of gray

Table 3. Reduction Stages

\begin{tabular}{|c|c|c|c|c|c|c|c|}
\hline & \multirow{2}{*}{ Area $\mathbf{A}$} & \multicolumn{2}{|c|}{ Area C } & \multirow{2}{*}{ Area P1 } & \multirow{2}{*}{ Area P2 } & \multirow{2}{*}{$\begin{array}{l}\text { Sewer } \\
\text { Line }\end{array}$} & \multirow{2}{*}{ TOTAL } \\
\hline & & ST & Unit & & & & \\
\hline Primary Flakes & 0 & 1 & 0 & 1 & 0 & 1 & 3 \\
\hline Secondary Flakes & 0 & 3 & 19 & 2 & 0 & 1 & 25 \\
\hline Tertiary Flakes & 5 & 228 & 323 & 61 & 1 & 3 & 621 \\
\hline Cores & 0 & 2 & 0 & 1 & 0 & 0 & 3 \\
\hline Points \& Bifaces & 0 & 3 & 2 & 15 & 0 & 0 & 20 \\
\hline Chips \& Chunks & 0 & 11 & 23 & 19 & 0 & 1 & 54 \\
\hline Other & 0 & 4 & 0 & 0 & 0 & 0 & 4 \\
\hline TOTAL & 5 & \multicolumn{2}{|c|}{619} & 99 & 1 & 6 & 730 \\
\hline
\end{tabular}



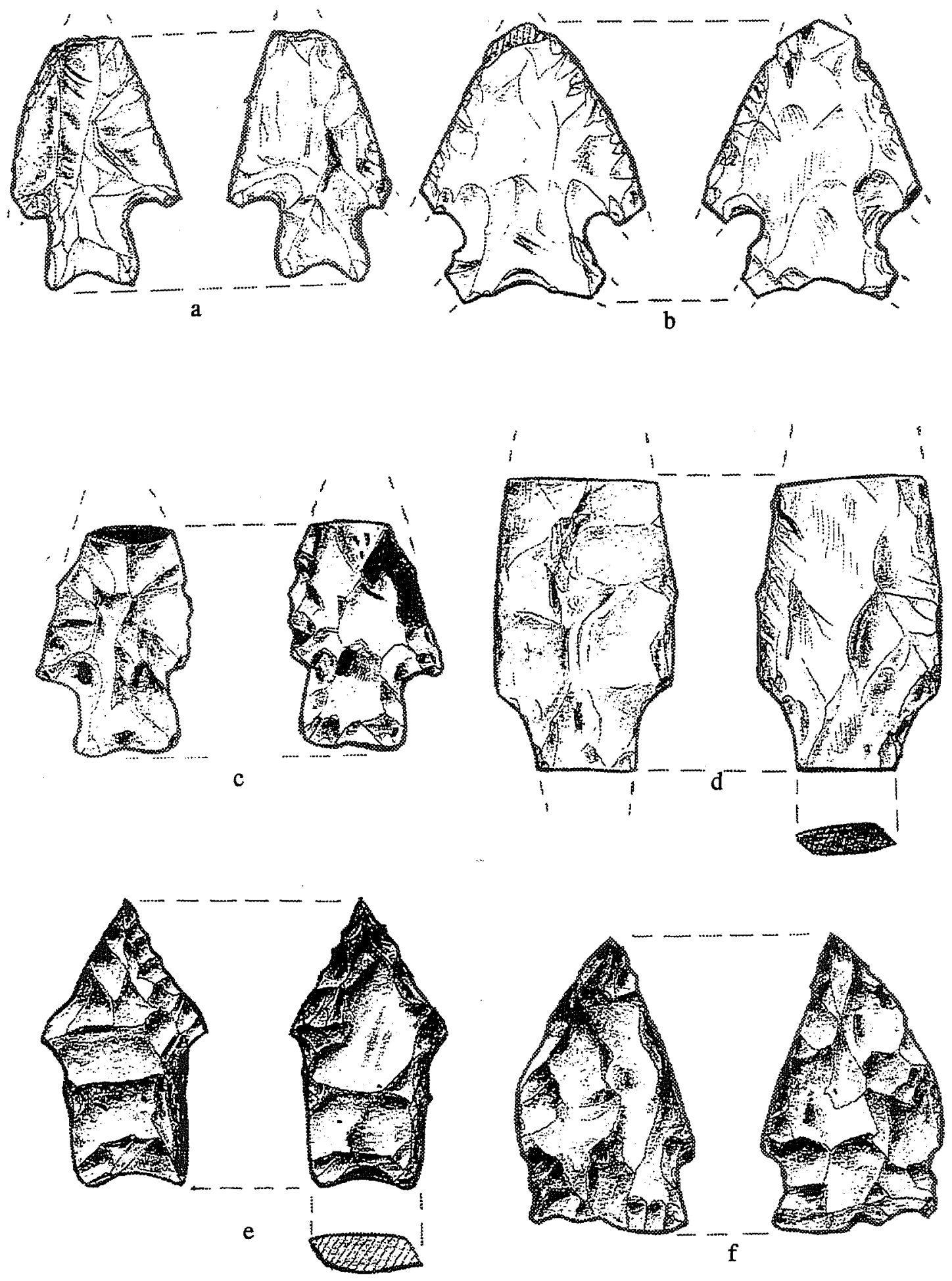

Figure 6. Projectile points. a. Gower (UI 2); b. Uvalde (UI3); c. Uvalde (UI4); d. Nolan (UI6); e. Nolan (UI8); f. Ensor-like (UI1). All shown actual size. 
chert with inclusions and is heavily patinated on both sides. Maximum width at shoulders: $2.5 \mathrm{~cm}$, thickness: $0.8 \mathrm{~cm}$.

Uvalde point, Unique Item 3 (Figure 6b).

This point was found on the surface in the northwest section of Area P1 on the Tla terrace. Both barbs and basal tips-as well as the distal tip-are broken. It is made of gray chert with inclusion much like UI 2 and also has a similar amount of patination. Maximum width at shoulders: $3.2 \mathrm{~cm}$, thickness: $0.4 \mathrm{~cm}$.

Uvalde point, Unique Item 4 (Figure 6c).

This point was found on the surface in the western section of Area P1 on the Tla terrace. The distal tip of this point is missing. It is made of dark brown chert and is patinated on both sides. Maximum width at shoulders: $2.4 \mathrm{~cm}$, thickness: $0.7 \mathrm{~cm}$.

\section{Middle Archaic}

Nolan point, Unique Item 6. (Figure 6d).

This point was recovered from a depth of $30 \mathrm{~cm}$ below surface during excavation of the $1-x-1-m$ unit in Area $\mathrm{C}$ on the Tla terrace. It is represented by a medial fragment with part of the alternately beveled stem remaining. Material is a dark brown chert exhibiting patination on one side. Maximum width: $2.6 \mathrm{~cm}$, thickness: $0.7 \mathrm{~cm}$.

Nolan point, Unique Item 8 (Figure 6e).

This point was recovered from a depth of $15-50 \mathrm{~cm}$ below surface in the preliminary shovel test excavated in 1993 in our Area C on the Tla terrace. It is made of dark brown chert. Maximum length: $4.1 \mathrm{~cm}$, maximum width: $2.5 \mathrm{~cm}$, thickness: $0.6 \mathrm{~cm}$.

\section{Late Archaic}

Ensor-like point, Unique Item 1 (Figure 6f). This point was recovered from the surface in the general area of 41BX50, on the extreme eastern edge of P1 on the T1b terrace. It is made of dark brown chert with an expanding base and weakly side-notched shoulders. Evidence of retouching is present along one side and light patination is found along one edge. Maximum length: $4.3 \mathrm{~cm}$, maximum width: $2.7 \mathrm{~cm}$, thickness: $0.7 \mathrm{~cm}$.

\section{Cores}

Three cores are included in the lithic collection, all from shovel tests within the redefined boundaries of 41BX47. Two of these were found at a depth of $10-20 \mathrm{~cm}$ below the surface, the third at $20-30 \mathrm{~cm}$ below surface.

Flakes, Chips, and Chunks

Most of the artifacts recovered during the project consist of unmodified chert flakes (primary, secondary, and tertiary) and flake fragments (chips and chunks). Artifacts from these two categories comprise 96 percent $(n=703)$ of the total lithic collection. Of these, tertiary flakes account for 85 percent $(n=621)$ of the total collection with primary $(n=3)$, secondary $(n=25)$, and chips and chunks $(n=54)$ accounting for only 11 percent.

\section{ARTIFACT DISTRIBUTION}

\section{Horizontal Distribution}

Patterns of horizontal density distribution were derived using the total number of artifacts recovered from each shovel test (Figure 7). Low density areas (L) are those with 1-4 artifacts per test. Medium areas (M) have 5-9 artifacts per test, and those with 10 or more are classified as high density areas $(\mathrm{H})$. The smaller low, medium, and high density pockets in the southwestern portion of the site are from shovel tests performed in the concentrations associated with the Early Archaic projectile points and are located on the Tla terrace. The chronological association of the large low density area on the east side of the site is unknown. 
This page has been

redacted because it

contains restricted

information. 


\section{Vertical Distribution}

Of the 730 artifacts recovered, 318 came from shovel tests with controlled-depth provenience. Table 4 illustrates the homogeneous vertical distribution of the artifacts recovered from the shovel tests by area. The remaining 412 artifacts came from the surface $(n=20)$, backhoe trenches $(n=15)$, the preliminary shovel test during the initial 1993 site visit $(n=9)$, and the $1-x-1-m$ excavation unit $(n=368)$. The even vertical distribution of the lithics from the shovel tests is repeated in the 1-x-1-m unit distribution with 29 percent $(\mathrm{n}=105)$ from $0-20 \mathrm{~cm}, 37$ percent $(n=136)$ from $20-40 \mathrm{~cm}$, and 34 percent $(n=127)$ from $40+\mathrm{cm}$.

\section{SITE FORMATION PROCESSES}

\section{Gravel Content}

An analysis of the gravel content of the sediments was conducted to address the role of Leon Creek flood episodes in site formation processes at 41BX47. Conditions for in situ preservation would have been adversely affected by high magnitude flood events; these events are indicated where gravel frequencies are over 30 percent. The percents of gravels in each 10-cm level containing artifacts are compared in Figure 8. Levels with low gravel percentages (less than 30 percent) contain more than 83 percent $(n=266)$ of the total number $(n=317)$ of artifacts. Looking at the distribution of artifacts by percent of gravel, a clear bimodal distribution is present. This suggests that some of the artifacts, especially in the high gravel-bearing levels, may have been transported by fluvial processes, but the great majority probably were not greatly displaced by flood events. Most of the artifacts occur in fine-grained sediments with dispersed gravels, and these deposits are characterized by Nordt (Appendix) as likely to have originated by a meandering stream experiencing nonflashy discharge.

\section{Size Sorting and Edge and Ridge Damage}

Artifacts from three 10-cm levels within the 1-x-1-m unit were examined for fluvial transport and bioturbation evidence, such as size sorting and edge and ridge damage - two recognizable effects of water transport on lithic material (Schiffer 1987). The deposition of artifacts carried by flowing water will vary according to size and

Table 4. Vertical Distribution of Artifacts from Shovel Tests

\begin{tabular}{|c|c|c|c|c|c|c||}
\hline Area & $\mathbf{0 - 1 0} \mathbf{~ c m}$ & $\mathbf{1 0 - 2 0} \mathbf{c m}$ & $\mathbf{2 0 - 3 0} \mathbf{c m}$ & $\mathbf{3 0 - 4 0} \mathbf{c m}$ & $\mathbf{4 0 - 5 0} \mathbf{~ c m}$ & $\mathbf{5 0 +} \mathbf{~ c m}$ \\
\hline A & 2 & 1 & 1 & 0 & 1 & 0 \\
\hline C & 56 & 61 & 47 & 30 & 35 & 11 \\
\hline P1 & 11 & 16 & 7 & 18 & 13 & 1 \\
\hline P2 & 0 & 0 & 1 & 0 & 0 & 0 \\
\hline SL & 2 & 0 & 0 & 0 & 4 & 0 \\
\hline TOTAL & $\begin{array}{c}\mathbf{7 1} \\
\mathbf{( 2 2 \% )}\end{array}$ & $\begin{array}{c}\mathbf{7 8} \\
\mathbf{( 2 4 \% )}\end{array}$ & $\begin{array}{c}\mathbf{5 6} \\
\mathbf{( 1 8 \% )}\end{array}$ & $\begin{array}{c}\mathbf{4 8} \\
\mathbf{( 1 5 \% )}\end{array}$ & $\begin{array}{c}\mathbf{5 3} \\
\mathbf{( 1 7 \% )}\end{array}$ & $\begin{array}{c}\mathbf{1 2} \\
\mathbf{( 4 \% )}\end{array}$ \\
\hline
\end{tabular}




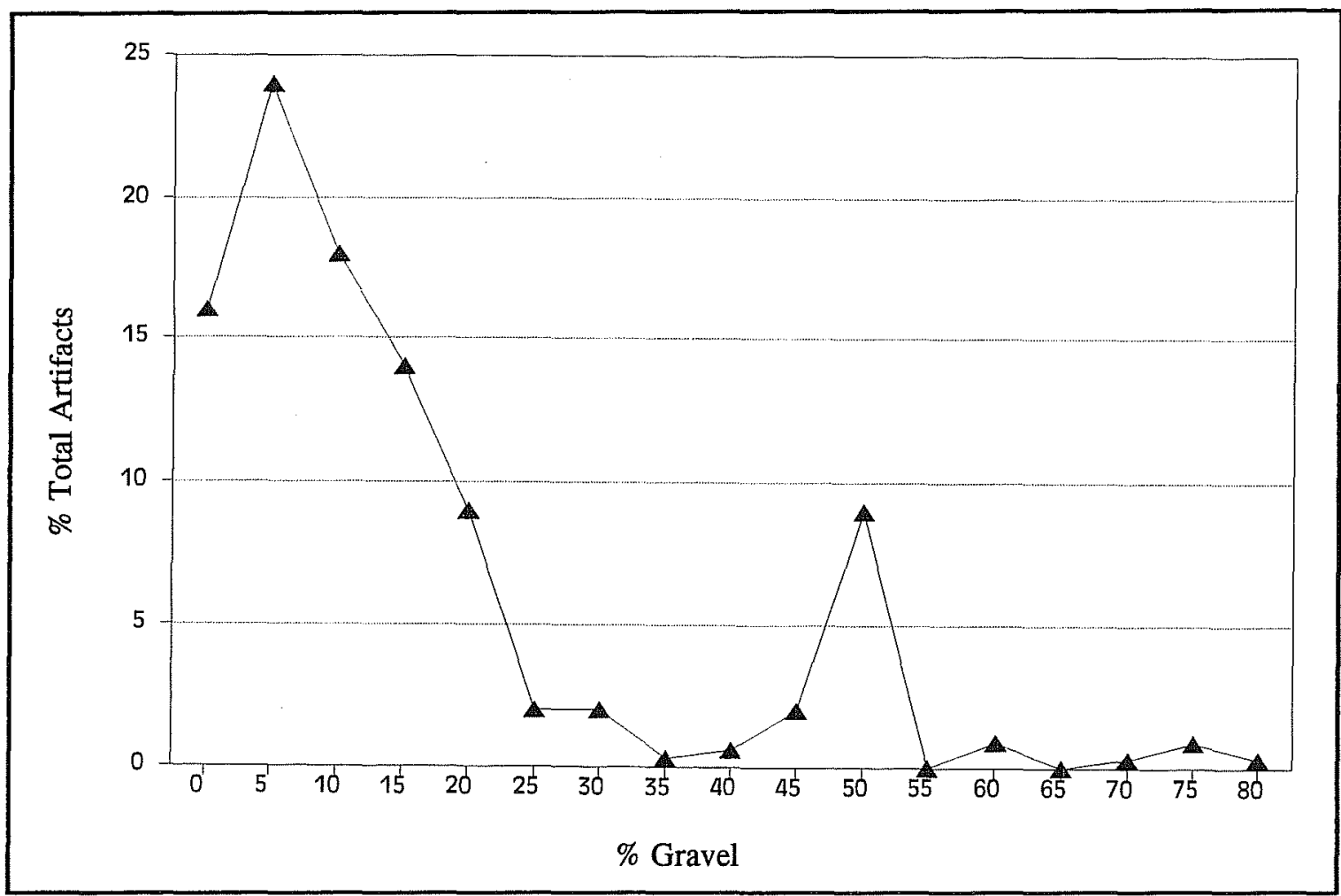

Figure 8. Gravel and artifact frequency comparison.

transport velocity, leaving size-sorted deposits. Abrasions, battering, and ridge- and edgesmoothing on lithic artifacts all result from contact with water-borne materials and/or stream rolling associated with water transport.

To identify the presence and possible extent of these non-cultural processes at 41BX47, artifacts from three levels in the $1-x-1-m$ unit were examined. The levels chosen were: $10-20 \mathrm{~cm}$ below surface, $40-50 \mathrm{~cm}$ below surface (directly above the gravel layer), and $50-60 \mathrm{~cm}$ below surface (within the gravel layer). Individual artifacts from this sample set were classified using the following set of attributes:
Weight (grams)

Edge modification or damage:

None,

Light with fresh edges remaining,

Bifacial with light edge damage,

Light damage on all edges,

Light battering with fresh edges remaining, Battering on all edges.

The weight distribution of the lithics in the sample does not present a clear pattern either for or against size sorting due to fluvial transport. A larger sample from the next test phase could be more informative. However, the edge damage analysis (Table 5) shows a correlation between the severity of damage to artifacts and the amount of gravel in a layer. Over 95 percent $(n=127)$ of artifacts from the two levels above the gravels show very light or no edge damage, while over half (59 percent, $n=23$ ) the lithics from 
Table 5. Analysis of Edge Damage

\begin{tabular}{|c|c|c|c|}
\hline Depth below surface & $\begin{array}{c}10-20 \mathrm{~cm} \\
(\mathrm{n}=53)\end{array}$ & $\begin{array}{c}40-50 \mathrm{~cm} \\
(\mathrm{n}=78)\end{array}$ & $\begin{array}{c}50-60 \mathrm{~cm} \\
(\mathrm{n}=39)\end{array}$ \\
\hline Gravel in matrix & $5 \%$ & $15 \%$ & $40 \%$ \\
\hline $\begin{array}{l}\text { Mean Weight (g)/STD } \\
\text { Min/Max }\end{array}$ & $\begin{array}{c}2.75 / \pm 7.29 \\
0.20 / 38.00\end{array}$ & $\begin{array}{c}0.85 / \pm 1.04 \\
0.10 / 3.82\end{array}$ & $\begin{array}{c}2.58 / \pm 5.24 \\
0.11 / 21.77\end{array}$ \\
\hline \multicolumn{4}{|l|}{ Edge Damage } \\
\hline None & $\begin{array}{l}34 \% \\
(18)\end{array}$ & $\begin{array}{l}50 \% \\
(39)\end{array}$ & $0 \%$ \\
\hline Light w/fresh edges & $\begin{array}{c}60.4 \% \\
(32)\end{array}$ & $\begin{array}{c}48.7 \% \\
(38)\end{array}$ & $\begin{array}{c}41.1 \% \\
(16)\end{array}$ \\
\hline Bifacial w/light damage & $\begin{array}{c}1.9 \% \\
(1)\end{array}$ & $0 \%$ & $0 \%$ \\
\hline Light all edges & $0 \%$ & $0 \%$ & $\begin{array}{c}17.9 \% \\
(7)\end{array}$ \\
\hline Light battering/some edges & $\begin{array}{c}3.8 \% \\
(2)\end{array}$ & $\begin{array}{c}1.3 \% \\
\text { (1) }\end{array}$ & $\begin{array}{c}7.7 \% \\
\text { (3) }\end{array}$ \\
\hline Battering/all edges & $0 \%$ & $0 \%$ & $\begin{array}{c}33.3 \% \\
(13)\end{array}$ \\
\hline
\end{tabular}

within the gravels have damage associated with water transport. This difference suggests fluvial processes may have been responsible for deposition or disturbance of artifacts associated with higher gravel content, while the light damage to the lithics in the upper levels indicates that, if transport was involved in their deposition, it was minimal and of short duration.

\section{EVALUATING SHOVEL TEST SAMPLING INTERVALS}

The information from this survey has been used to address an issue of increasing importance in cultural resource management archaeology: determining an efficient and effective method of site survey. This topic is of particular interest in areas like south-central Texas, where, aside from numerous burned-rock middens, site visibility is low. Simple surface inspection as a site discovery method, used successfully in the Greater Southwest where artifact concentrations can be easily seen due to sparse ground cover, is not always effective in South Texas. The low visibility of archaeological sites makes them difficult to detect under conditions of moderate to heavy ground cover.

The use of shovel tests is a long-accepted method of locating archaeological sites in areas such as these. However, shovel tests are expensive in both time and labor and, at present, the sampling design is usually informal, with the placement, intervals, and depths based on judgement. To enhance sampling rigor, the Texas Historical Commission is working on recommendations for survey intervals, dependent on geographic setting. Recent discussions of optimal spacing of shovel tests tend to be regionally focused and relate to evaluating sites once they are located (Krakker et al. 1983; Lynch 1980; McManamon 1984; Wobst 1983). Currently few studies evaluate the efficacy of 
sampling designs appropriate for site discovery in the region.

For this analysis, we have used the information from a 12-acre portion of the study area tested on a grid at $20-\mathrm{m}$ intervals. This data set was used experimentally to determine if similar results would have been obtained if shovel tests were placed at $40-\mathrm{m}$ intervals rather than $20-\mathrm{m}$. The results of the $20-\mathrm{m}$ and $40-\mathrm{m}$ interval samples were compared for three site and artifact attributes: site boundaries, horizontal artifact density distributions, and vertical artifact density distributions.

Figure 9 compares the site boundaries based on the $20-\mathrm{m}$ interval data versus those based on $40-\mathrm{m}$ intervals. The black dots represent the shovel tests within the $20-\mathrm{m}$ grid that contained artifacts. Tests that did not contain artifacts are not shown, but extend along each of the grid lines. The solid line represents the site boundary established using these tests. The asterisks represent the tests that would have been dug if a $40-\mathrm{m}$ grid had been used, and the dotted line is the site boundary that would have been established. Except for the outermost shovel tests which contained artifacts, site boundaries changed very little when spacing was increased to 40-m intervals.

Horizontal artifact density distributions are plotted with contour lines and are based on total artifacts recovered per shovel tests (Figure 10). The low density $(L)$ areas yielded 1 to 4 artifacts, the medium density (M) areas produced 5 to 9 artifacts, and the high density areas $(\mathrm{H})$ had 10 or more. The solid lines and letters are based on the $20-\mathrm{m}$ information, the dotted lines and open letters on $40-\mathrm{m}$ data. Figure 10 shows the overall patterns do not change substantially.

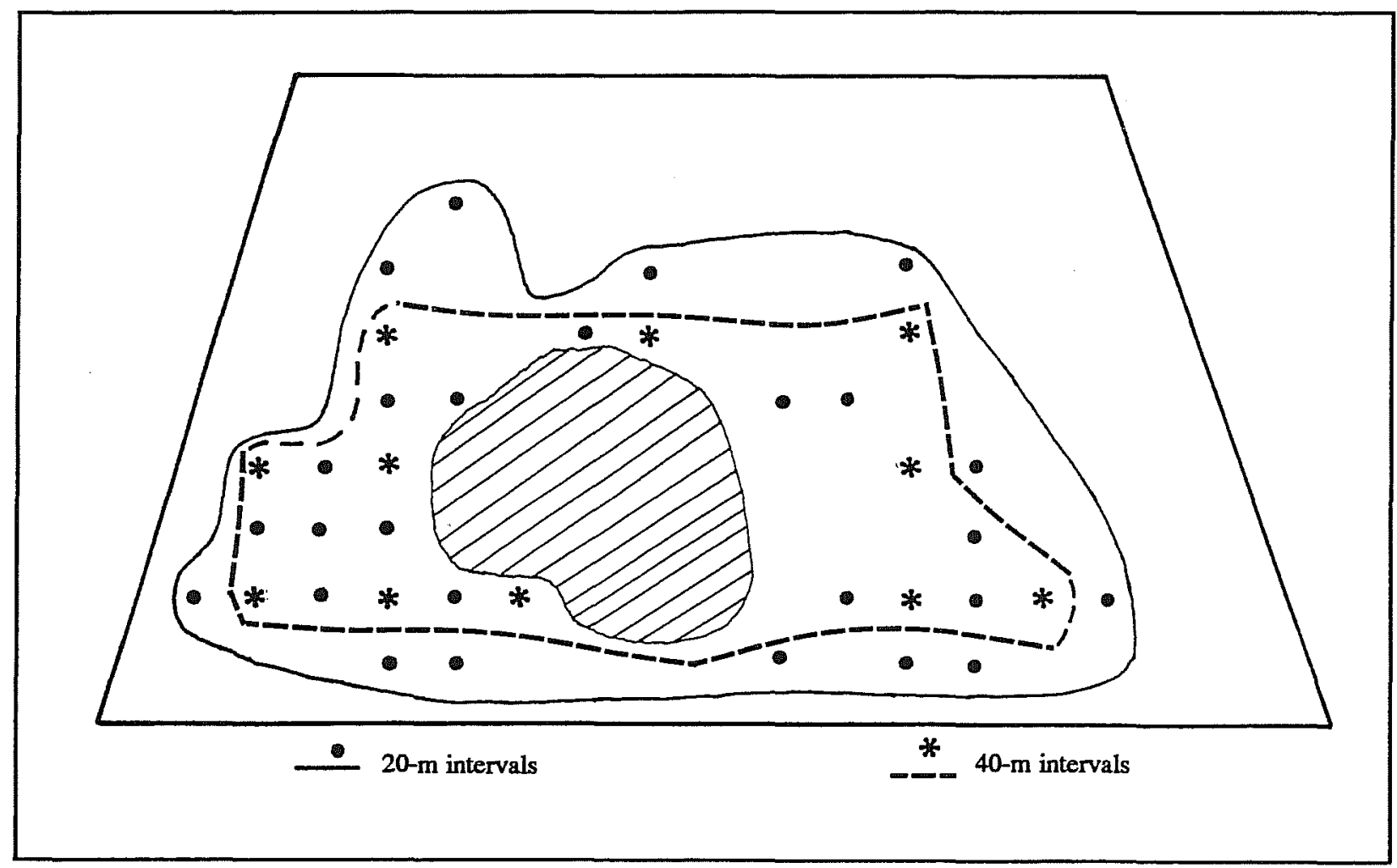

Figure 9. Site boundary comparison. 
Vertical artifact densities per 10-cm level are compared in Figure 11. The $\mathrm{X}$ axis represents the $10-\mathrm{cm}$ levels, the $Y$ axis is the average number of artifacts recovered from each level. The $20-\mathrm{m}$ interval data reflect an even distribution of between .32 and .47 artifacts per $10-\mathrm{cm}$ level. The $20-\mathrm{m}$ interval data is then compared to two different $40-\mathrm{m}$ interval samples. The central bars, representing the 40-m subset used in the two previous charts, show a heavier concentration of artifacts (.8 artifacts per $10-\mathrm{cm}$ level) in the upper $20 \mathrm{~cm}$, decreasing to .05 or fewer in the bottom $30 \mathrm{~cm}$. The last bar in each set, a second $40-\mathrm{m}$ subset, shows an opposite pattern with .4 artifacts the first $10 \mathrm{~cm}$, increasing to .8 in the lowest level. Chi-square tests for goodness of fit and significance were run on these figures and, as illustrated in the chart, there is a significant difference between the results of the $20-\mathrm{m}$ and $40-\mathrm{m}$ interval tests in this category.
These comparisons suggest that 26 shovel tests at 40-m intervals compared to 107 tests at $20-\mathrm{m}$ intervals would have produced very similar site boundaries and density distributions. However, detailed information about site contexts and contents would have been significantly altered. While these results may only be applicable to sites with similar size, density, and artifact distributions, they do indicate the potential significance of further sampling experiments. Once a large set of experimental results is compiled, it may become feasible to develop a body of data that could enhance the efficiency of fieldwork through tested sampling designs. Eventually archaeologists may have access to a developed body of proven sampling strategies based on archaeological context, visibility, and geomorphological setting.

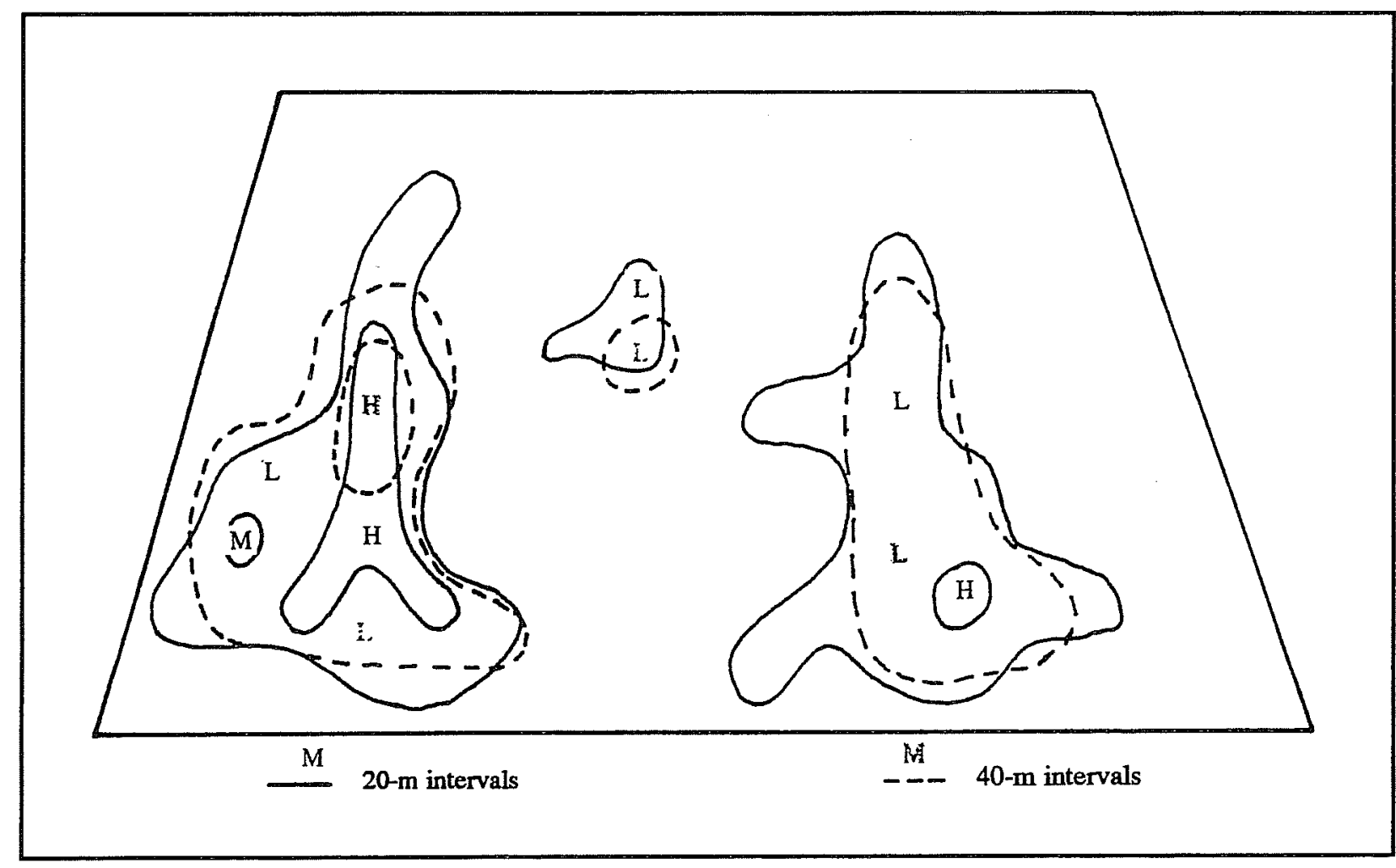

Figure 10. Density comparison. 


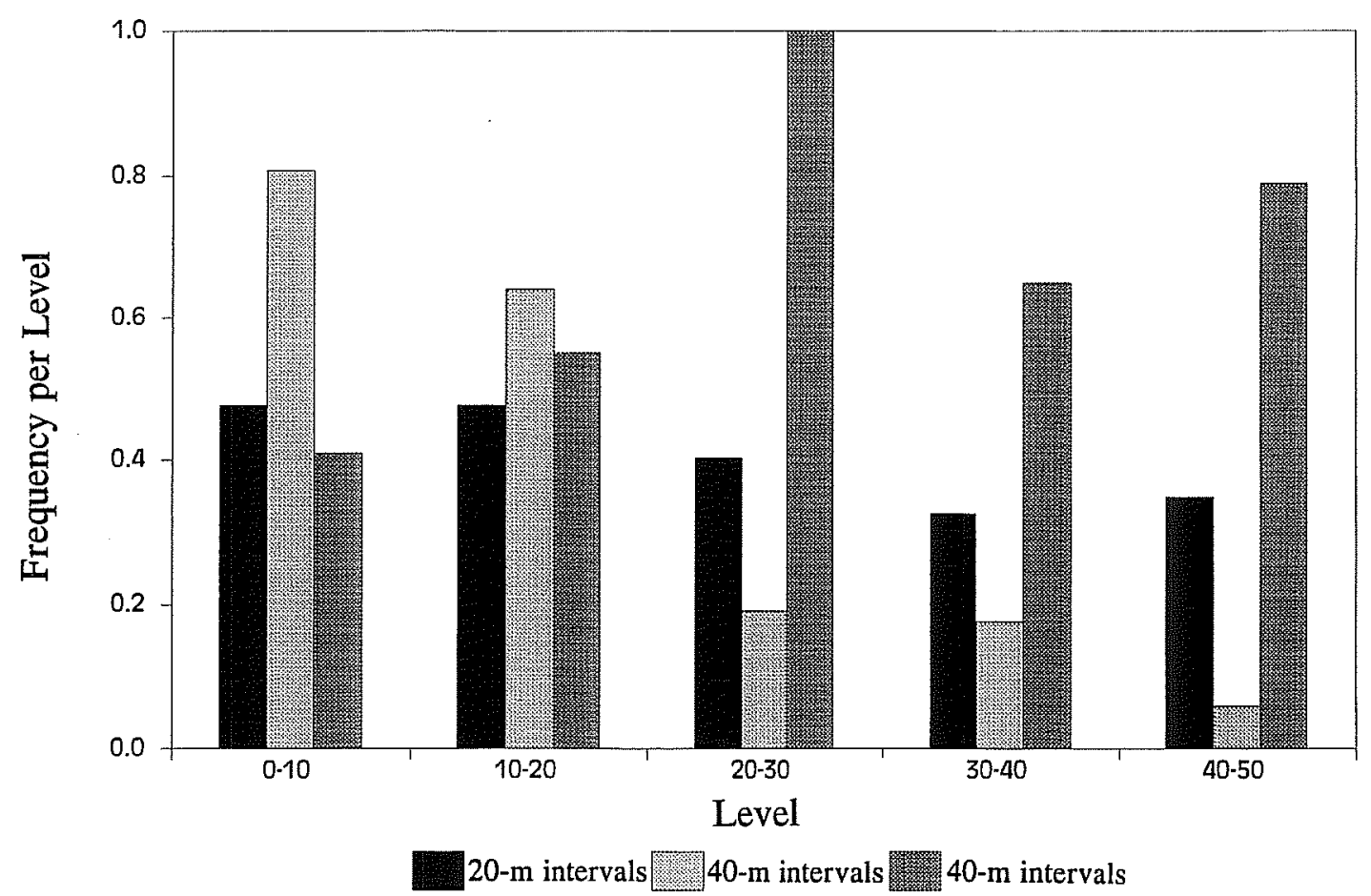

Figure 11. Artifact frequency comparison.

\section{DISCUSSION}

Reports on excavations of two central Texas sites with well-defined components from the early portion of the Archaic period have recently been published. Both of these sites, the Camp Pearl Wheat site in Kerr County (Collins et al. 1990) and the Sleeper site in Blanco County (Johnson 1991), are located north of 41BX47 on terraces above small creeks that feed the Guadalupe and Colorado rivers respectively. Both sites contain artifact assemblages similar to the one at $41 \mathrm{BX} 47$, including Gower, Uvalde, Bell, and Martindale points from the Sleeper site; and Martindale, Uvalde, and Bell from Camp Pearl Wheat. Both sites were excavated in large-block fashion for maximum horizontal exposure of discrete features.

Features identified at the Sleeper site were placed in three categories. "Baking heaps" were described as single or double, often elongated, layers of burned rock built flat on the ground. Johnson
(1991) argues that a fire was built directly on these rocks. After the fire went out and the rocks were thoroughly heated, the ashes were swept away and food placed directly on the rocks for cooking. Several smaller, stone-lined, slightly basin-shaped cooking hearths were also identified. Two mano caches with slightly used manos make up the third category of features. Fragments of 38 metates and 70 manos were recovered along with 8,854 pieces of lithic debitage.

Features from the Camp Pearl Wheat site are described by Collins et al. (1990) as six slightly ovate hearths of burned limestone formed in shallow pits. Archeomagnetic testing and organic residue analysis of selected rocks from these features suggest that these hearths served different functions. Some rocks were shown to have cooled in place while others were deposited after cooling. Organic residue from both plants and animals was present on the rocks tested. No ground stone artifacts were reported from this site. 
Johnson (1991) identified a crescent-shaped concentration of 10 Early Archaic period sites extending from the Del Rio area to north of San Antonio. Based on analysis of the tool assemblages, he proposes major site-specific activities for each site. Hunting/butchering activities were very important at nine of the 10 sites. Milling was of major import at two of the sites and of minor import at two others, as were early stage knapping and woodworking.

While these two reports contribute to our understanding of adaptations during the early part of the Archaic period in central Texas, they also point out how little is known about this period. Little or no information exists on types of flora and fauna exploited, nor the settlement patterns which incorporated use of Hill Country alluvial terraces. Answers to these questions cannot be found through survey projects alone. However, with thorough investigation of probably intact, temporally distinct sites such as $41 \mathrm{BX} 47$, substantial additions can be made to our knowledge of past adaptations.

\section{CONCLUSIONS}

A systematic study of the proposed water storage project area using a mix of shovel tests, plowing, walking survey, and one test unit, as well as a geomorphological study and artifact analyses, determined that 41BX47 covers approximately 30 acres or over 25 percent of the study area. Our findings regarding the other previously recorded sites are as follows: $41 \mathrm{BX} 40$ is actually part of 41BX47; 41BX48 no longer exists; and 41BX50 is heavily damaged but the small remaining portion may contain intact deposits.

Horizontal and vertical distribution analyses of artifacts from $41 \mathrm{BX} 47$ identified areas of high, medium, and low densities containing lithic materials evenly distributed vertically within the upper $50 \mathrm{~cm}$ across a large portion of the site. The recent human disturbances to the site are limited to the immediate area of the borrow pit in Area C and minimal disturbance from previous plowing activities in Area P1. The primary natural site formation process that may have altered the integrity of the deposits is alluvial action.

Archaeological and geomorphological investigations indicate 41BX47 may contain three spatially distinct components. A Middle Archaic deposit is found in the northwest part of the site at the edge of the Tla terrace in the top $50 \mathrm{~cm}$ of sediment. In these levels the brown sandy loams and sandy clay loams have a low proportion of gravels. The diagnostic tools found in this component indicate this occupation may be Middle Archaic in age and span the period between roughly 5000 and 2500 B.P. Regarding the integrity of this component, Nordt (Appendix, p. 36) indicates there is a "moderate to high probability of site preservation ... where the sediments are relatively gravel-free in the upper 50 $\mathrm{cm}$, flood water velocities would have been less, with a subsequent increase in the potential for site preservation in relatively undisturbed contexts." Further, our analyses of the chipped stone artifacts recovered from the 1-x-1-m test unit from levels above $50 \mathrm{~cm}$ where gravels were few exhibited only minor damage from fluvial action. In contrast, the 50-60-cm level contained substantially more gravels and the artifacts exhibited more battering and edge damage, probably from stream action. The evidence at this time indicates there is a high potential for recovering intact deposits from the upper $50 \mathrm{~cm}$ near the margin of the Tla terrace. It is precisely this context from which the highest density of artifacts, as well as scattered burned rock, has been identified in the northwest corner of the site.

An Early Archaic deposit, found on the surface and in the upper levels of the Tla terrace, contains diagnostic tools that suggest this occupation may span a period between 7500 and 5500 B.P. According to Nordt (Appendix), the gravel content of the upper $50-100 \mathrm{~cm}$ of the Tla reaches as much as 10-15 percent in clay loam sediments. These deposits have been subjected to flashy floods that would have destroyed some occupations. However, in the upper part of the Tla terrace, where water velocities were lower as evidenced by finergrained deposits and lower proportions of gravel, there is greater potential site integrity (Nordt, Appendix). This surface will not contain sites older than the Early Archaic but could contain sites 
spanning the Middle Archaic to present. Thus far, the diagnostic projectile points found on the T1a are Early Archaic in age. The potential for site preservation below 50 to $100 \mathrm{~cm}$ is minimal due to the abundance of gravels (Nordt, Appendix). Nearly all cultural material from the T1a has been recovered on the surface or within upper $50 \mathrm{~cm}$ where gravel content is low.

The third archaeological component lies buried $80-110 \mathrm{~cm}$ below the surface within the Tlb terrace in the southeast portion of the site. Nordt (Appendix) has outlined two possible geomorphological histories with discrete chronological implications for the Tlb sediments. The first is that the Tlb was formed as part of the same depositional system which formed Tla and it therefore originates from the Middle Holocene with an age range of 8000 to 5000 B.P. The second possibility is that the $\mathrm{T} 1 \mathrm{~b}$ deposits were formed during the Late Pleistocene or Early Holocene (11,000-8000 B.P.) as part of the underlying cemented gravels. A Texas Highway Department project found a buried Paleoindian component approximately two kilometers to the north along Leon Creek at site 41BX52. Artifacts from this component consist primarily of large, heavily patinated flakes. In contrast, the flakes from the buried component at 41BX47 are small with little patination, suggesting they are unrelated to the Paleoindian component at 41BX52. However, an assessment of the geomorphological relationships between the two sites must wait until the $41 \mathrm{BX} 52$ material is published.

While it appears that the weight of the evidence suggests that the buried component is Middle Holocene in age, without radiocarbon dates and soil analyses these alternative interpretations cannot be resolved. This component may be largely intact, due to the slow and uniform sedimentation of the Tlb floodbasin facies (Nordt, Appendix). Further, existing buried archaeological components may be vertically segregated rather than collapsed in narrow zones (Nordt, Appendix), enhancing the potential for unmixed archaeological deposits. However, without further data from this component, such as features, diagnostics, radiocarbon assays, assemblage characteristics, horizontal distribution, and preservation, it is difficult to assess its research potential.

Site $41 B X 47$ may be eligible for inclusion in the National Register under Criterion D, in that it may have the potential to contribute significant information to our understanding of the Early and Middle Archaic and possibly Late Paleoindian periods of prehistory of the region. Data from the site could be used to address significant research issues concerning hunter-gatherer adaptations including the organization of settlement systems, subsistence, and lithic technology as well as paleoenvironmental data. However, a program of testing is required to further evaluate the research potential of the site so that eligibility may be appropriately assessed.

\section{RECOMMENDATIONS}

A testing program for $41 \mathrm{BX} 47$ should address specific issues related to determination of the site's significance. These issues include: 1 ) the presence of intact features; 2) the existence of intact artifact clusters; 3 ) the presence of faunal and floral material; and 4) the further evaluation of horizontal and vertical integrity of the site.

The recommended testing program should use both hand-excavated test units and machine-excavated horizontal exposures to obtain the needed data. Hand-excavated test units should yield artifact samples that can then be used to assess the degree of fluvial transport, recover floral and faunal samples, obtain diagnostic tools, recover data concerning differential artifact densities, and make preliminary assessments of the lithic technology. Horizontal exposures should be excavated with a Gradall to search for features and to identify artifact clusters.

A stratified sampling design should be used to place both the hand-excavated and Gradall units. The design would be based on the low, medium, and high artifact density areas, noncultural areas, untested areas, and the buried component identified during the present phase of investigation. 
Approximately $151-\mathrm{x}-1-\mathrm{m}$ test units and 20 Gradall trenches should be distributed in the low, medium, and high density areas strata. Portions of the site containing a low density of material should be sampled at a less intense level, while the medium and high density areas should be tested with a greater intensity. All areas of the site need to be tested to obtain comparative samples. The precise location of the units within each strata would be judgmental. Four of the 1-x-1-m units should be excavated to test the buried component. The first $70 \mathrm{~cm}$ of these four units can be excavated with the Gradall, with the final $50 \mathrm{~cm}$ excavated by hand. Larger, 1-x-2-m units are appropriate due to the depth.

Gradall trenches should be used to search for buried features and artifact clusters. Five centimeters of sediment would be scraped away with each pass of the Gradall. As each level is mechanically removed, archaeologists would walk over the scraped surface and record exposed features and artifacts. If a feature were encountered, the Gradall would cease scraping in its vicinity. The feature would be mapped and selected features would be tested or excavated to recover radiocarbon, floral, artifactual, and morphological data. The backdirt from the Gradall would be monitored for diagnostics.

Additional geomorphological analyses should be conducted to assess the age and origin of the upper terrace. Further analysis of the upper $50-\mathrm{cm}$ deposit may reveal where a recent flood drape lies. Lee Nordt of Texas A\&M University would conduct field analysis of profiles and laboratory soil characterizations.

Following completion of the fieldwork and data analysis, recommendations regarding the eligibility of the site for inclusion in the National Register of Historic Places would be made.

\section{EPILOGUE}

Prior to the publication of this report, CAR completed the recommended intensive testing program designed to address specific issues related to the significance and eligibility of $41 B \times 47$ for inclusion under Criterion D in the National Register of Historic Places. This second phase of archaeological investigation consisted of 14 $1-\mathrm{x}-1-\mathrm{m}$ and one $.5-\mathrm{x}-1-\mathrm{m}$ hand-excavated test units, 59 Gradall trenches, and additional geomorphological study (Tennis 1996). The second phase of work verifies the existence of intact Early and Middle Archaic components identified in this report and adds additional information on newly identified Late Paleoindian and Late Archaic components. The second phase of geomorphological investigations led to extensive revisions of the site geomorphology in this report (Nordt 1996).

The Phase II investigations revealed 79 burnedrock features and 24 diagnostic projectile points from the Late Paleoindian and Early, Middle, and Late Archaic time periods. The features appear in undisturbed context and represent elements of three horizontally and vertically stratified components.

The Middle to Late Archaic component consists of two, possibly three, large midden-like accumulations of extensively cracked limestone and several hearths. Wood charcoal from one of the hearths (Beta sample number 82228 ) yielded a radiocarbon age of $4390 \pm 50$ B.P. (tree-ring calibrated to 5240 [4970, 4940, 4880] 4840 B.P. at 2 sigma). These features are found from $10-30 \mathrm{~cm}$ below the surface in two areas along the west and northwest edge of the site and are associated with Bulverde, Pedernales, Kinney, Marshall, Pandora, and Marcos points.

The Early Archaic component is represented by two large oven-like accumulations of lightly cracked and uncracked burned limestone and over 50 small hearths. These features occur from $40-110 \mathrm{~cm}$ below the surface, primarily in the eastern portion of the site and occur at depths that also revealed Early Corner-Notched, Gower, and Hoxie projectile points.

The Late Paleoindian component consists of three lightly burned hearths from $120-180 \mathrm{~cm}$ below the surface revealed in a $1-x-1-m$ unit in the northern portion of the site. At a depth of $125 \mathrm{~cm}$ below the surface, a Late Paleoindian Angostura point was 
recovered from between two hearth features. Wood charcoal was recovered from an additional intact feature $170 \mathrm{~cm}$ below the surface in the same unit. This charcoal (Beta sample number 82227) produced a radiocarbon age of $7920 \pm 50$ B.P. (treering calibrated to 8960 [8700, 8660] 8520 B.P. at 2 sigma). The component buried at $80-110 \mathrm{~cm}$ in the Tlb terrace on the southeastern side of the site could not be verified during Phase II testing.

Without question 41BX47 has the potential to contribute substantial data to the understanding of past environmental change and human adaptations through the recovery of paleoenvironmental and archaeological data from this unique and significant site. Site 41BX47 is thus considered eligible for inclusion in the National Register of Historic Places. 


\section{REFERENCES CITED}

Black, S. L.

1989 Central Texas Plateau Prairie. In From the Gulf Coast to the Rio Grande: Human Adaptation in Central, South and Lower Pecos Texas, by T. R. Hester, S. L. Black, D. G. Steele, B. W. Olive, A. A. Fox, K. J. Reinhard, and L. C. Bement, pp. 17-38. Research Series No. 33. Arkansas Archeological Survey, Fayetteville.

Black, S. L., and A. J. McGraw

1985 The Panther Springs Creek Site: Cultural Change and Continuity in the Upper Salado Creek Drainage, South-Central Texas. Archaeological Survey Report, No. 100. Center for Archaeological Research, The University of Texas at San Antonio.

Collins, M. B., B. Ellis, and C. Dodt-Ellis

1990 Excavations at the Camp Pearl Wheat Site (41KR243): An Early Archaic Campsite on Town Creek, Kerr County, Texas. Studies in Archeology 6. Texas Archeological Research Laboratory, The University of Texas at Austin.

Hester, T. R.

1978 Early Human Occupations in South Central and Southwestern Texas: Preliminary Papers on the Baker Cave and St. Mary's Hall Sites. Center for Archaeological Research, The University of Texas at San Antonio.

1991 The Plainview Points from the St. Mary's Hall Site, South Central Texas. La Tierra 18(2):1-4.

Johnson, L., Jr.

1986 A Plague of Phases. Bulletin of the Texas Archeological Association 57:1-26.

1991 Early Archaic Life at the Sleeper Archaeological Site 41BC65 of the Texas Hill Country, Blanco County, Texas. Publications in Archaeology, Report No. 39. Texas State Department of Highways and Public Transportation, Austin.

Johnson, L., and G. T. Goode

1994 A New Try at Dating and Characterizing Holocene Climates, as well as Archeological Periods, on the Eastern Edwards Plateau. Bulletin of the Texas Archeological Association 65:1-51.

Krakker, J. J., M. J. Shott, and P. D. Welch

1983 Design and Evaluation of Shovel-Test Sampling in Regional Archaeological Survey. Journal of Field Archaeology 10:469-480.

Lynch, B. M.

1980 Site Artifact Density and the Effectiveness of Shovel Probes. Current Anthropology 21:516-517.

McGraw, A. J., and K. Hindes

1987 Chipped Stone and Adobe: A Cultural Resources Assessment of the Proposed Applewhite Reservoir, Bexar County, Texas. Archaeological Survey Report, No. 163. Center for Archaeological Research, The University of Texas at San Antonio. 
McManamon, F. P.

1984 Discovering Sites Unseen. In Advances in Archaeological Method and Theory, edited by M. B. Schiffer, 7:223-292. Academic Press, Orlando.

Nordt, L. C.

1996 Geoarchaeology of 41BX47: Upper Leon Creek Basin. In Archaic Land Use of Upper Leon Creek Terraces: Archaeological Testing in Northern Bexar County, Texas, by C. L. Tennis. Archaeological Survey Report, No. 234. Center for Archaeological Research, The University of Texas at San Antonio. In press.

Potter, D. R., S. L. Black, and K. Jolly

1995 Archeology Along the Wurzbach Parkway: Module 1 Introduction, Conceptual Framework, and Contexts of Archeological Investigations in Bexar County, South-Central Texas. Studies in Archeology, No. 17. Texas Archeological Research Laboratory, The University of Texas at Austin.

Prewitt, E. R.

1981 Cultural Chronology in Central Texas. Bulletin of the Texas Archeological Society 52:65-89.

1985 From Circleville to Toyah: Comments on Central Texas Chronology. Bulletin of the Texas Archeological Society 54:201-238.

Schiffer, M. B.

1987 Formation Processes of the Archaeological Record. University of New Mexico Press, Albuquerque.

Stothert, K.

1989 The Archaeology and Early History of the Headwaters of the San Antonio River. Southern Texas Archaeological Association Special Publication No. 5 and Incarnate Word Archaeology Series No. 3, San Antonio.

Taylor, F. B., R. B. Hailey, and D. L. Richmond

1991 Soil Survey of Bexar County, Texas. Soil Conservation Service, United States Department of Agriculture, Washington, D.C.

Tennis, C. L.

1996 Archaic Land Use of Upper Leon Creek Terraces: Archaeological Testing in Northern Bexar County, Texas. Archaeological Survey Report, No. 234. Center for Archaeological Research, The University of Texas at San Antonio. In press.

Thoms, A. V.

1992 Late Pleistocene and Early Holocene Regional Land Use Patterns: A Perspective from the Preliminary Results of Archaeological Studies at the Richard Beene Site, 41BX831, Lower Medina River, South Texas. In Guidebook, 10th Annual Meeting, South-Central Friends of the Pleistocene: Late Cenozoic Alluvial Stratigraphy and Prehistory of the Inner Gulf Plain, South-Central Texas, edited by R. Mandel and C. Caran. Quaternary Research Center Series No. 4 (draft). Lubbock Lake Landmark, Texas Tech University, Lubbock.

Turner, E. S., and T. R. Hester

1993 A Field Guide to Stone Artifacts of Texas Indians. Second edition. Gulf Publishing, Houston. 
Uecker, H. G.

1992 The UTSA Boulevard Project: Archaeological Survey Along Leon Creek in Northwest San Antonio, Texas. Archaeological Survey Report, No. 216. Center for Archaeological Research, The University of Texas at San Antonio.

Wobst, H. M.

1983 We Can't See the Forest for the Trees: Sampling and the Shapes of Archaeological Distributions. In Archaeological Hammers and Theories, edited by J. A. Moore and A. S. Keene, pp. 37-85. Academic Press, New York. 


\title{
APPENDIX \\ GEOARCHAEOLOGY OF THE UPPER LEON CREEK BASIN
}

\author{
Lee C. Nordt
}

\section{INTRODUCTION}

The focus of the geoarchaeological investigation was the upper late Quaternary alluvial basin of Leon Creek. The objectives were to 1) spatially and chronologically delineate alluvial environments of deposition, and 2) assess the influence of these environments on preservation potentials for the archaeological record.

\section{STUDY AREA}

Leon Creek is a major tributary of the Medina River in central Texas. The study area is located in a late Quaternary alluvial setting of Leon Creek, about $20 \mathrm{~km}$ below the headwaters. Above the study area, isolated pockets of alluvium fill an entrenched limestone valley, while below the study area the alluvial valley is continuous.

Most of the Leon Creek basin drains the Cretaceous Edwards Limestone undivided and the Anacacho Limestone (Barnes 1983). These geologic units contributed mostly limestone and some chert to the alluvial valley of Leon Creek during the late Quaternary.

\section{METHODS}

The late Quaternary alluvial record of Leon Creek within the study area was constructed from 17 backhoe trenches (selected trench localities are shown in Figure A-1), numerous bore holes (Raba-Kistner 1994), one cutbank exposure, the Castle Sands 7.5 minute topographic map (U.S. Geological Survey 1992), and the Soil Survey of Bexar County, Texas (Taylor et al. 1966). The chronological framework was based on timediagnostic cultural artifacts and correlations to other central Texas alluvial stream histories.

Soil-stratigraphic descriptions were written following standards and procedures of the Soil Survey Staff (1981) and Holliday (1990). Alluvial stratigraphic units were informally defined as unconformably bound packages of sediment having unique spatial and chronological distributions. The cultural divisions referred to in this report follow Prewitt (1981, 1985).

\section{ALLUVIAL STRATIGRAPHIC SUMMARY}

Two terraces and three stratigraphic units were identified and mapped in the study area (Figures A-1 and A-2). The two terraces were mapped as $\mathrm{T} 1$ and T0. Based on an intervening 1-2 $\mathrm{m}$ topographic scarp, Terrace 1 (T1) was subdivided into $\mathrm{T} 1 \mathrm{a}$ and $\mathrm{T} 1 \mathrm{~b}$ components. Terrace 0 (T0) demarcates the modern floodplain and is separated from $\mathrm{T} 1$ by a $1-\mathrm{m}$ topographic scarp. Late Pleistocene and Early to Middle Holocene alluvial units form the Tla and T1b sediment-assemblages, while a Late Holocene unit forms the T0 sedimentassemblage. Without radiocarbon dating, two working chronological hypotheses are presented for the alluvial stratigraphic history of upper Leon Creek basin. 
This page has been

redacted because it

contains restricted

information. 


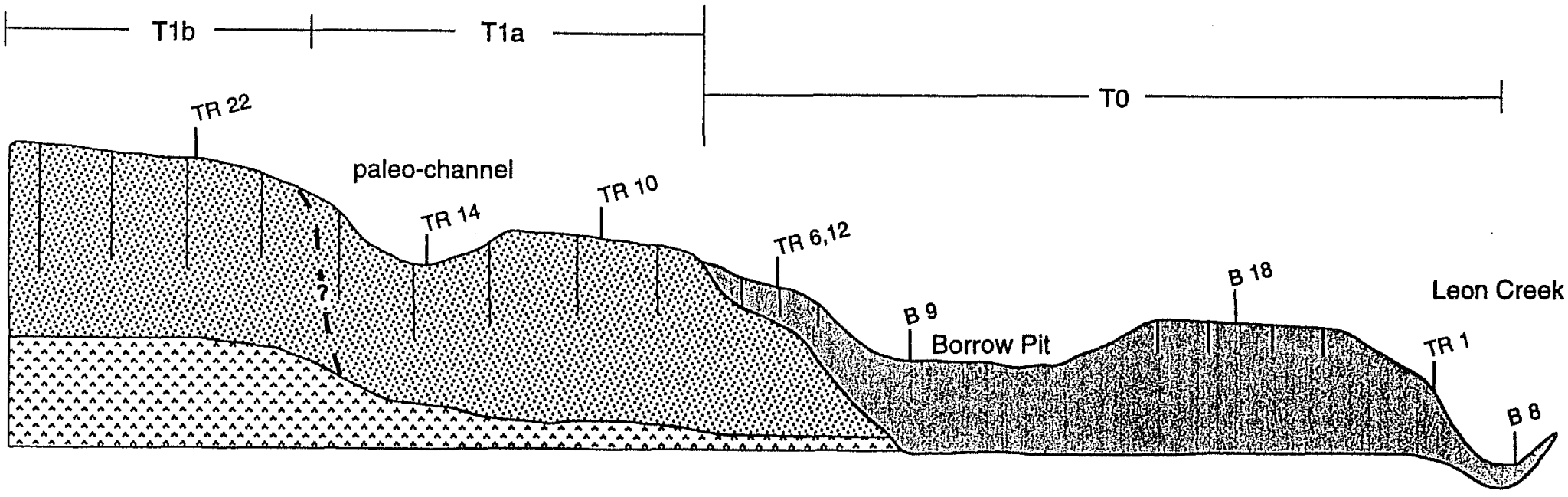

\section{ALLUVIAL UNITS}

Late Holocene and Moderm

23 Early or Middle Holocene

Late Pleistocene or Early Holocene

\section{LANDFOHMS}

To

T1a Middle Holocene terrace

T1b Early or middle Holocene terrace

\section{SOIL UNITS}

TTT Late Holocene and Modem

TT Early or mlddle Holocene

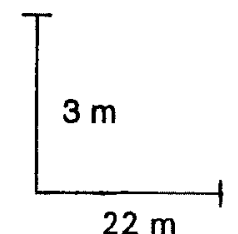

Figure A-2. Schematic late Quatemary alluvial geologic cross-section of Leon Creek. Horizontal and vertical scales were estimated from topographic maps (see Figure 1-A), backhoe trenches, and bore holes (Raba-Kistner 1994). Selected descriptions-sample localities are shown in estimated positions. Thickness of the Middle Holocene alluvial fill was estimated from the Cretaceous contact identified in Trenches 1 and B-8, and from similar stream fills at Fort Hood, Texas (Nordt 1992). See Addendum for selected soil-stratigraphic description. 


\section{TERRACE $1(\mathrm{~T} 1)$}

\section{Stratigraphy}

Terrace $1 \mathrm{~b}(\mathrm{~T} 1 \mathrm{~b})$ is about $5-6 \mathrm{~m}$ above the modern Leon Creek channel thalweg (low water channel) and gently slopes to the north and west (Figure A-1). This terrace component is underlain by an estimated 6-m alluvial fill (Figure A-2). Trench 22 reveals that between a depth of 3.2 and $2.8 \mathrm{~m}$ the fill consists of alternating beds of carbonatecemented gravels $(0.5-2 \mathrm{~cm}$ diameter) and unconsolidated orange-tan sands (Addendum). Well-sorted, grain-supported gravels indicate deposition by a paleo-meandering stream receiving nonflashy discharge.

The sediments exposed in the upper $2.8 \mathrm{~m}$ of Trench 22 consist of a thin bed of unconsolidated basal gravels $(0.5-2 \mathrm{~cm}$ in diameter) contained within a reddish-tan matrix overlain by a thick bed of light beige silty clay loam (Addendum). The sediments within this unit were calcareous throughout. Some of the detrital carbonate (limestone) has been dissolved and reprecipitated into pedogenic filaments and threads between a depth of about 40 and $150 \mathrm{~cm}$, with hard carbonate segregations (nodules) about $1 \mathrm{~cm}$ in diameter occurring between a depth of 110 and $150 \mathrm{~cm}$. Trench 16 reveals the same soil character and light beige silty clay loam texture down to at least $2.9 \mathrm{~m}$.

Terrace 1a (T1a) is situated to the north and west of $\mathrm{Tlb}$ approximately $4 \mathrm{~m}$ above the modern Leon Creek thalweg (Figures A-1 and A-2). As shown in Trenches $4,10,13$, and 14, the Tla sedimentassemblage displays a calcareous fining upward sequence beginning with basal gravels (up to $8 \mathrm{~cm}$ in diameter) which grade up into strong brown clay loams (see Addendum for descriptions of Trenches 10 and 14). Gravel beds typically extend up to within $0.25-1 \mathrm{~m}$ of the ground surface. This sedimentary sequence suggests that the unit was deposited by a low sinuosity meandering bed load (graveliferous) stream. As with the soil beneath $\mathrm{T} 1 \mathrm{a}$, filaments and threads of secondary $\mathrm{CaCO}_{3}$ occur between depths of about 30 and $120 \mathrm{~cm}$. No $\mathrm{CaCO}_{3}$ segregations or gravel pendants (pedogenic carbonate coatings on gravel bottoms) were observed in soils of the Tla sediment-assemblage.

\section{Chronology}

The pea- to golfball-size cemented gravels exposed near the base of Trench 22 in the T1b sedimentassemblage are much smaller than those beneath T1a or T0 (Figures A-1 and A-2; Addendum). Small, well-sorted gravels, coupled with tan matrix colors, are similar to the deeply buried, early Holocene (11,000-8000 в.P.) Georgetown alluvium recognized at Fort Hood in central Texas (Nordt 1992).

Two factors suggest that the deposits of the Tla sediment-assemblage and the fine-grained upper deposits of the $\mathrm{Tlb}$ sediment-assemblage were deposited coevally as part of the same depositional system (facies-related): 1) they have similar matrix colors, textures, and degree of soil development; and 2) they contain cultural debris. Because the soils developed in both the T1a and T1b sedimentassemblages are calcareous in the surface horizons, no differential carbonate leaching between the two soils has occurred, indicating they are similar in age.

Cultural materials consist of flakes at about a meter depth in Trench 22 of the Tlb sedimentassemblage and Nolan, Uvalde, and Gower points identified on the surface and in test pits within the upper meter of the T1a sediment-assemblage. The time-diagnostic points indicate that aggradation of the Tla sediment-assemblage and the upper part of the $\mathrm{T} 1 \mathrm{~b}$ sediment-assemblage terminated shortly after 5000-6000 B.P. Assuming the consolidated gravels at the base of Trench 22 of T1b were deposited between 11,000 and 8000 B.P. (as discussed above), aggradation of the channel fill beneath $\mathrm{Tla}$ and the associated overbank deposits beneath Tlb could have begun as early as 8000 B.P. The age range of 8000-5000 B.P. and the reddish brown colors for the alluvium beneath T1a and the upper part of Tlb are similar to the Middle Holocene Fort Hood alluvium from Fort Hood, Texas (Nordt 1992); the Middle Holocene Medina paleosol from the Medina River (Thoms and 
Mandel 1992); and the latter part of the Early Holocene fill of the Pedernales River (Blum and Valastro 1989).

The increase in gravel size and decrease in gravel sorting in the Tla-sediment, as compared to the base of the $\mathrm{T} 1 \mathrm{~b}$ sediment-assemblage, suggests a change in channel flow regime from uniform, lowenergy flood magnitudes in the late Pleistocene and Early Holocene to more flashy flood magnitudes in the Middle Holocene.

Without radiocarbon dating, a second working chronological hypothesis must be considered. The 1-2-m scarp separating $\mathrm{Tla}$ and $\mathrm{T} 1 \mathrm{~b}$ may represent a morphostratigraphic (units defined by surface topography only) erosional unconformity separating two differently aged stratigraphic units (Figures A-1 and A-2). Assuming the $\mathrm{CaCO}_{3}$ segregations at about $1 \mathrm{~m}$ depth in Trenches 22 and 16 are pedogenic, and with the knowledge that they do not occur in soils of the Tla sedimentassemblage, the T1b soils are older than the soils associated with $\mathrm{Tla}$ (soil and isotopic analyses are needed to resolve this problem). Accordingly, the soils associated with T1b would have been developing in an overbank facies chronologically related to the underlying late Pleistocene/early Holocene cemented gravels, and not to the middle Holocene channel gravels associated with Tla. This hypothesis does not alter chronological interpretations of Tla.

\section{Geoarchaeology}

If the fine-grained sediments in the upper $2.0 \mathrm{~m}$ of the Tlb sediment-assemblage and the channel gravels in the Tla sediment-assemblage are overbank and channel facies of the same depositional system related and deposited between about 8000 and 5000 B.P., Early Archaic sites could be contained within both. The floodbasin facies of the T1b sediment-assemblage would have been more suitable for burial of intact sites because of slow and uniform, nonepisodic sedimentation. The absence of buried soils within this unit suggests that sites spanning the Early Archaic will be vertically separated and not compressed within narrow zones.
Site preservation within the channel facies of the Tla sediment-assemblage below a depth of 50$100 \mathrm{~cm}$ will be minimal because of the abundance of coarse gravels. The water velocity needed to carry these gravels would have concomitantly reworked most cultural deposits. However, there is still a possibility that sites are preserved within local fine-grained channel fills.

The uppermost $50-100 \mathrm{~cm}$ of the Tla sedimentassemblage often contain gravels, from 0-15 percent, diffusely distributed within a clay loam matrix. In areas having 10-15 percent gravels, aggradation by an initial high magnitude flood surge was probably followed by flood recession and infilling of gravel interstices with clays. This process would have invariably destroyed some sites, while preserving them in areas where flood water velocities and gravel contents were lower (personal observations, Fort Hood, Texas). Furthermore, many individual sites and burned rock middens are preserved with contextual integrity in the upper part of, and on, Middle Holocene alluvial units at Fort Hood that are similar in character and have experienced the same flashy flood history as the Tla sedimentassemblage on Leon Creek (Nordt 1992; Mueller-Wille and Carlson 1990). Consequently, there is potential for site preservation within the upper part of, and on, the Tla sedimentassemblage.

The consolidated gravels deeply buried within the T1b sediment-assemblage could contain Paleoindian sites, although intervening loamy layers would have greater potential for preservation.

Consistent with time-diagnostic artifacts from the study area, the T1a surface will not contain sites older than the late Early Archaic. Because this surface has been available for occupation for the last 5,000 years, it may also contain sites spanning the Middle Archaic to present; two Middle Archaic points have been found here. The same would be true of $\mathrm{Tlb}$, although only one time-diagnostic artifact-a Transitional Archaic period point-has been discovered on this surface. 
Most areas on Tla and T1b have not been disturbed by gravel quarrying. However, Trench 10 contains a 9-cm-thick surface fill that appears to be related to quarrying of an adjacent borrow pit (Addendum). The identification of this layer as disturbed fill was based on an abrupt and broken contact between the fill layer and the first undisturbed soil horizon below, unhomogenized pockets varying in color and texture within the fill, and the presence of filaments and threads of secondary $\mathrm{CaCO}_{3}$ at depths too shallow for the effective wetting depth of the area (implying removal of some of the original soil) (Nordt and Hallmark 1990). This interpretation eliminates the possibility of surface site preservation in the immediate vicinity of the trench. However, in the relatively gravel-poor zone between depths of 9 and $25 \mathrm{~cm}$, buried sites could be preserved in relatively undisturbed contexts.

Following the alternative working chronological hypothesis presented in the stratigraphic section, the T1a and T1b sediment-assemblages could represent spatially and chronologically distinct stratigraphic units. Accordingly, the fine-grained deposits in the upper 2-3 m of the Tlb sedimentassemblage would most likely be late Pleistocene to Early Holocene in age (11,000-8000 B.P.) and could contain Paleoindian sites, while nearly the entire known cultural record for central Texas would be compressed on the Tlb surface. Preservation potentials within the upper $2 \mathrm{~m}$ of fine-grained sediments beneath $\mathrm{T} 1 \mathrm{~b}$ would be high. Geoarchaeological interpretations for the Tla sediment-assemblage under the alternative hypothesis would not change from that of the original hypothesis.

\section{TERRACE 0 (T0)}

\section{Stratigraphy}

Terrace 0 (T0) is the active floodplain of Leon Creek. Unfortunately, most of the area mapped as the T0 sediment-assemblage has been disturbed by gravel quarrying. However, numerous bore holes (Raba-Kistner 1994) show that the T0 sedimentassemblage is primarily a graveliferous unit. A surface layer of loamy and sandy sediments $0.5-2 \mathrm{~m}$ thick overlie the gravels in some areas. Cutbank exposure A (Figure A-1) shows an undisturbed section of this assemblage that was deposited by a tributary entering Leon Creek from the southeast. The gravels in this exposure are poorly sorted, range in diameter from pea-size to boulders, are matrix supported, and lack imbrication. These properties indicate that deposition from some small tributaries of Leon Creek was occurring as a mass of unsorted sediment debris, or debris flow, typical of alluvial fans (Miall 1978). In B-18 and B-9 (Figure A-1; see Addendum for a description of B-18), however, the gravels appear to be grainsupported and fine upward slightly, indicating deposition by a bedload meandering stream. Apparently both debris flow and meanderbelt deposition were ongoing at this time.

The sedimentary sequences in Trenches 6 and 12 suggest that the T0 sediment-assemblage overlaps the Tla sediment-assemblage along the margins of T1a (Figures A-1 and A-2; Addendum). The T0 sediment-assemblage is represented by the upper $50-60 \mathrm{~cm}$ of sediments in these trenches and consists of brown sandy loams and sandy clay loams with low gravel content and weakly developed soil properties. These textures are in contrast to the silty clay loam textures common to the T1a sediment-assemblage. The T0 sedimentassemblage in Trench 6 overlies dense graveliferous deposits that appear to correlate with gravels associated with the Tla sedimentassemblage.

As revealed in Trench 5 of the T0 sedimentassemblage, Cretaceous shales are exposed at a depth of about $1.3 \mathrm{~m}$, which is near the level of the modern channel thalweg. B-8 (Figures A-1 and A-2; Raba-Kistner 1994) shows that the base of the modern channel is cut about $1 \mathrm{~m}$ below this level. Consequently, channel deposits appear to be confined to the channel itself and perhaps laterally away from the channel only within acute meander bends. However, as discussed above, floodbasin deposits from the modern channel laterally onlap the margins of Tla. 


\section{Chronology}

About 4000 B.P. a shift in channel flow regime, followed by a brief period of channel erosion, occurred in many streams throughout central Texas (Blum and Valastro 1989; Nordt 1992; Thoms and Mandel 1992). This erosional event may have also cut the T0 valley along Leon Creek. As observed by Nordt (1992) along low-order tributaries at Fort Hood, Texas, and Blum and Valastro (1989) along the Pedernales River, Late Holocene sediments that filled these newly cut valleys were very graveliferous, similar to those beneath $\mathrm{T} 0$ of Leon Creek. Although these investigators also identified additional Late Holocene and modern units, the degree of disturbance of $\mathrm{T} 0$ prohibits further stratigraphic subdivisions within the Leon Creek study area. Therefore the T0 sediment-assemblage is assigned an age range of 4000 B.P. to present (Figures A-1 and A-2).

\section{Geoarchaeology}

The T0 sediment-assemblage has been severely disturbed in most areas by gravel quarrying. Disturbance, accompanied by thick graveliferous sediments deposited within a high-energy channel meanderbelt, demonstrates that site preservation either on the T0 surface or at depth within the T0 sediment-assemblage will be minimal. Although outside any visible quarried area, the upper $30 \mathrm{~cm}$ of sediment exposed in Trench 5 (not formally described) was clearly fill material, while sediments in Trench 1 appear to reflect a combination of in-situ-bedded flood deposits and mixed overburden material (Figure A-1). As a result, it seems that the only chance for recovering surface or buried cultural material in undisturbed contexts in this area would be within a few meters of the largest trees.

If sites were located in the T0 sedimentassemblage, they would be Middle Archaic to Historic and probably concentrated in loamy deposits in the upper $20-40 \mathrm{~cm}$ of the fill. This includes the margin of Tla where the T0 sedimentassemblage overlaps channel gravels associated with the Tla sediment-assemblage (Figure A-1, Trenches 6 and 12). The erosional contact separating the two fills in these trenches could represent a loss of as much as 1,000 years of sediment time (between about 5000 and 4000 B.P.) and part of the Middle Archaic record as well. Site recovery potentials will be nonexistent in debris flow deposits associated with the T0 sedimentassemblage.

\section{GEOARCHAEOLOGICAL CONCLUSIONS}

The highest probability for preservation of buried sites in relatively undisturbed contexts occurs in overbank deposits in the upper 2-3 m of the T1b sediment-assemblage. This interpretation is based on the presence of sediments which aggraded slowly and uniformly in a relatively low-energy floodbasin environment. Depending on the working chronological model invoked, late Paleoindian to Early Archaic records could be contained within these sediments, while sites within this age range or younger could be preserved on the terrace surface.

Moderate to high probability of site preservation occurs in the upper $50 \mathrm{~cm}$ of the Tla sedimentassemblage, and the upper $50 \mathrm{~cm}$ of the T0 sediment-assemblage where it onlaps Tla on the margins of the modern floodplain. Where gravel contents reach $10-15$ percent in the T1a sedimentassemblage, the velocity of flood waters would have presumably been great enough that some site disturbance may have occurred. However, where the sediments are relatively gravel-free and finegrained in the upper $50 \mathrm{~cm}$, flood water velocities would have been less, with a subsequent increase in the potential for site preservation in relatively undisturbed contexts. Sites dating to the Early Archaic may be found within this unit, while sites of this age and younger may be found on the terrace surface.

Low probabilities of site preservation occur in the basal graveliferous deposits of the Tla, T1b, and T0 sediment-assemblages. These deposits are encountered at a depth of about 2-3 $\mathrm{m}$ in the T1b sediment-assemblage and generally within the 
upper $50 \mathrm{~cm}$ in the $\mathrm{Tla}$ and $\mathrm{T} 0$ sedimentassemblages. However, because of the presence of fine-grained channel plugs within these deposits, there is still potential for site preservation dating to Paleoindian in the Tlb sediment-assemblage, to the Early Archaic in the T1a sediment-assemblage, and to the Middle and Late Archaic in the T0 sediment-assemblage.

\section{FURTHER WORK}

To eliminate one of the chronological working hypotheses proposed for the alluvial history of the T1a and T1b sediment-assemblages, carbon-14 dating is needed. A humate age from a $2-\mathrm{m}$ depth in Trench 22 or 16 of the T1b sedimentassemblage (Figure A-1) would reveal whether the floodbasin deposits are facies-related and the same age as the 5000-6000 B.P. channel deposits of the T1a sediment-assemblage. The age of the overbank deposits beneath $\mathrm{T} 1 \mathrm{~b}$ will have a profound influence on the expected ages of the buried archaeological record in this area.

Another approach would be to relatively date the T1a and T1b soils by determining the $\mathrm{CaCO}_{3}$ content of each. If the soils associated with the $\mathrm{Tlb}$ sediment-assemblage are indeed older than the soils developed in the Tla sediment-assemblage, there should be some $\mathrm{CaCO}_{3}$ loss evident in the upper horizons of the T1b soil. During field reconnaissance, the surface horizons of the $\mathrm{Tlb}$ soil may have reacted strongly to $\mathrm{HCl}$ only because of the incorporation of recent carbonatic flood deposits into the soil by plowing. Reaction with $\mathrm{HCl}$ cannot effectively distinguish differing amounts of $\mathrm{CaCO}_{3}$.

Lastly, determining with certainty whether the carbonate nodules in the T1b soil are pedogenic or limestone clasts is important if the former is to be used as an indicator of landscape age. A combination of thin section and stable-carbonisotope analyses on the carbonate segregations would resolve this problem. 


\section{REFERENCES CITED}

Barnes, V. E.

1983 Geologic Atlas of Texas: San Antonio Sheet. Bureau of Economic Geology, The University of Texas at Austin.

Blum, M. D., and S. Valastro, Jr.

1989 Response of the Pedernales River of Central Texas to late Holocene Climatic Change. Annals of the Association of American Geographers 79:435-456.

Holliday, V. T.

1990 Pedology in Archaeology. In Archaeological Geology of North America, edited by N. P. Lasca and J. Donahue, pp. 525-540. Geological Society of America Centennial Special Volume 4, Boulder, Colorado.

Miall, A. D.

1978 A Review of the Braided-River Depositional Environment. Earth-Science Reviews 13:1-62.

Mueller-Wille, C. S., and D. L. Carlson

1990 Archaeological Survey at Fort Hood, Texas, Fiscal Year 1985, and Other Training Areas. U.S. Army Fort Hood Archaeological Resource Management Series, Research Report No. 21. Archaeological Research Laboratory, Texas A\&M University, College Station.

Nordt, L. C., and C. T. Hallmark

1990 Soil-Geomorphology Field Guidebook. Departmental Technical Report 90-7. Department of Soil and Crop Sciences. Texas A\&M University, College Station.

Nordt, L. C.

1992 Archaeological Geology of the Fort Hood Military Reservation, Fort Hood, Texas. U.S. Army Fort Hood Archaeological Resource Management Series, Research Report Number 25. Archaeological Research Laboratory, Texas A\&M University, College Station.

Prewitt, E. R

1981 Cultural Chronology in Central Texas. Bulletin of the Texas Archaeological Society 52:65-89.

1985 From Circleville to Toyah: Comments on Central Texas Chronology. Bulletin of the Texas Archaeological Society 54:201-238.

Raba-Kistner Consultants, Inc.

1994 Geotechnical Engineering Study for Proposed Leon Creek Reservoir, San Antonio. Report on file at the Center for Archaeological Research, The University of Texas at San Antonio.

Soil Survey Staff

1981 Soil Survey Manual. U.S. Department of Agriculture-Soil Conservation Service, Agriculture Handbook 18. U.S. Government Printing Office, Washington, D.C.

Taylor, F. B., R. B. Hailey, and D. L. Richmond

1966 Soil Survey of Bexar County. U.S. Department of Agriculture-Soil Conservation Service. U.S. Government Printing Office, Washington, D.C. 
Thoms, A. V., and R. D. Mandel

1992 The Richard Beene Site: A Deeply Stratified Paleoindian to Late Prehistoric Occupation in South-Central Texas. Current Research in the Pleistocene 9:43-44. 


\section{ADDENDUM \\ Soil-Stratigraphic Descriptions}

\begin{tabular}{|c|c|c|}
\hline \multicolumn{3}{|c|}{ Trench 14; T1a; Middle Holocene channel deposit; 947 feet; calcareous throughout. } \\
\hline A1 & $0-18 \mathrm{~cm}$ & $\begin{array}{l}\text { black (10YR } 2 / 1) \text { clay loam; strong fine subangular blocky; very hard; } \\
\text { few fine coarse fragments; many sand-sized carbonate grains; abrupt } \\
\text { smooth. }\end{array}$ \\
\hline $\mathrm{A} 2$ & $18-49 \mathrm{~cm}$ & $\begin{array}{l}\text { very dark brown (10YR } 2 / 2) \text { clay loam; moderate medium angular } \\
\text { blocky; very firm; few angular mostly carbonate clasts } 0.3-1 \mathrm{~cm} \\
\text { diameter; gradual smooth. }\end{array}$ \\
\hline Bk1 & $49-79 \mathrm{~cm}$ & $\begin{array}{l}\text { very dark grayish brown (10YR } 2.5 / 2) \text { clay loam; moderate medium } \\
\text { prismatic; firm; } 5-8 \% \text { diffusely distributed angular carbonate clasts } \\
0.3-1 \mathrm{~cm} \text { diameter and } 10 \% \text { diffusely distributed coarse fragments less } \\
\text { than } 0.3 \text { diameter; } 4-5 \% \text { carbonate filaments and threads; gradual } \\
\text { smooth. }\end{array}$ \\
\hline $\mathrm{Bk} 2$ & $79-118 \mathrm{~cm}$ & $\begin{array}{l}\text { strong brown ( } 7.5 \text { YR } 5 / 6) \text { sandy clay loam; weak coarse prismatic; } \\
\text { firm; } 10-15 \% \text { angular carbonate clasts } 0.5-1.5 \mathrm{~cm} \text { diameter; } 1 \% \\
\text { carbonate filaments and threads. }\end{array}$ \\
\hline $\mathrm{C} 1$ & $118-238 \mathrm{~cm}$ & $\begin{array}{l}\text { reddish yellow }(7.5 \mathrm{YR} 6 / 6) \text { alternating beds }(10 \mathrm{~cm} \text { each) of mostly } \\
\text { carbonatic gravels up to } 1 \mathrm{~cm} \text { diameter and carbonatic gravels up to } 5 \\
\mathrm{~cm} \text { diameter; subrounded and moderately well sorted gravels, matrix } \\
\text { supported in upper balf; below } 225 \mathrm{~cm} \text { gravels are } 8-10 \mathrm{~cm} \text { diameter. }\end{array}$ \\
\hline \multicolumn{3}{|c|}{ Trench 10; T1a; Middle Holocene channel deposit; 949 feet; calcareous throughout. } \\
\hline Ap & $0-9 \mathrm{~cm}$ & $\begin{array}{l}\text { (fill material); very dark brown (10YR } 2 / 2) \text { clay loam; weak coarse } \\
\text { angular blocky to platy; very hard; } 5-7 \% \text { diffusely distributed } \\
\text { carbonate coarse clasts up to } 1-\mathrm{cm} \text { diameter; abrupt wavy. }\end{array}$ \\
\hline Bk & $9-25 \mathrm{~cm}$ & $\begin{array}{l}\text { very dark grayish brown (10YR } 2.5 / 2 \text { ) sandy clay loam; weak coarse } \\
\text { angular blocky; very hard; } 10 \% \text { mostly carbonate coarse clasts } 0.3-1.5 \\
\text { cm diameter; } 3 \% \text { diffusely distributed carbonate filaments and threads; } \\
\text { clear wavy. }\end{array}$ \\
\hline $\mathrm{Bk} 2$ & $25-49 \mathrm{~cm}$ & $\begin{array}{l}\text { brown (10YR } 4 / 3 \text { ) light sandy clay loam; massive; } 50 \% \text { grain- } \\
\text { supported carbonate coarse clasts } 0.5-3 \mathrm{~cm} \text { diameter, moderately well } \\
\text { sorted, subrounded, grain-supported; } 2 \% \text { carbonate filaments and } \\
\text { threads. }\end{array}$ \\
\hline $\mathrm{Cl}$ & $49-70 \mathrm{~cm}$ & $\begin{array}{l}\text { dark yellowish brown (10YR } 4 / 4) \text { sandy loam; massive; } 60 \% \text { grain- } \\
\text { supported carbonate coarse clasts } 0.3-1 \mathrm{~cm} \text { diameter occasionally to } \\
2-3 \mathrm{~cm} \text { diameter, moderately well to well sorted, subrounded, grain- } \\
\text { supported. }\end{array}$ \\
\hline $\mathrm{C} 2$ & $70-135 \mathrm{~cm}$ & $\begin{array}{l}\text { yellowish brown }(10 \mathrm{YR} 5 / 6) \text { and brownish yellow }(10 \mathrm{YR} 6 / 6) \text { sand } \\
\text { with alternating } 10 \mathrm{~cm} \text { beds of grain-supported carbonate coarse } \\
\text { fragments } 0.5 \text { to } 2 \mathrm{~cm} \text { diameter, moderately well sorted, subrounded. }\end{array}$ \\
\hline
\end{tabular}




\begin{tabular}{|c|c|c|}
\hline \multicolumn{3}{|c|}{$\begin{array}{l}\text { Trench 6; T1a; Late Holocene floodbasin deposit over Middle Holocene channel deposit; } 945 \\
\text { feet; calcareous throughout. }\end{array}$} \\
\hline A & $0-26 \mathrm{~cm}$ & $\begin{array}{l}\text { (Late Holocene floodbasin); very dark grayish brown (10YR } 2.5 / 2) \\
\text { sandy clay loam; weak coarse angular blocky; very hard; gradual } \\
\text { smooth. }\end{array}$ \\
\hline $\mathrm{Bk} 1$ & $26-49 \mathrm{~cm}$ & $\begin{array}{l}\text { (Late Holocene floodbasin); dark brown (10YR 3/3) sandy clay loam; } \\
\text { weak coarse angular blocky; very hard; } 2 \% \text { mostly carbonate coarse } \\
\text { fragments } 0.5 \text { to } 1 \mathrm{~cm} \text { diameter; gradual smooth. }\end{array}$ \\
\hline $\mathrm{Bk} 2$ & $49-71 \mathrm{~cm}$ & $\begin{array}{l}\text { (Late Holocene floodbasin); dark yellowish brown (10YR 3.5/4) sandy } \\
\text { clay loam; weak coarse prismatic; hard; } 7-8 \% \text { diffusely distributed } \\
\text { carbonate coarse fragments } 0.3 \text { to } 1 \mathrm{~cm} \text { diameter; abrupt wavy. }\end{array}$ \\
\hline $2 \mathrm{C} 1$ & $71-80 \mathrm{~cm}$ & $\begin{array}{l}\text { (middle Holocene channel); dark yellowish brown (10YR } 4 / 4) \text {; sandy } \\
\text { clay loam; massive; } 60 \text { to } 70 \% \text { grain-supported carbonate coarse } \\
\text { fragments } 0.5-1 \mathrm{~cm} \text { diameter occasionally up to } 4 \mathrm{~cm} \text { diameter, } \\
\text { moderately well sorted, subrounded; clear wavy. }\end{array}$ \\
\hline $2 \mathrm{C} 2$ & $80-125 \mathrm{~cm}$ & $\begin{array}{l}\text { (middle Holocene channel); yellowish brown (10YR 5/4); massive; } \\
70 \% \text { grain-supported carbonate coarse fragments } 2-5 \mathrm{~cm} \text { diameter, } \\
\text { moderately well sorted. }\end{array}$ \\
\hline \multicolumn{3}{|c|}{$\begin{array}{l}\text { Trench 22; T1b; Early or Middle Holocene floodbasin deposit over latest Pleistocene or Early } \\
\text { Holocene channel deposit; } 954 \text { feet; calcareous throughout. }\end{array}$} \\
\hline A & $0-40 \mathrm{~cm}$ & Early or Middle Holocene floodbasin; medium brown silty clay loam. \\
\hline $\mathrm{Bk} 1$ & $40-80 \mathrm{~cm}$ & $\begin{array}{l}\text { light brown silty clay loam with filaments and threads of secondary } \\
\mathrm{CaCO}_{3} .\end{array}$ \\
\hline $\mathrm{Bk} 2$ & $80-110 \mathrm{~cm}$ & $\begin{array}{l}\text { Early or Middle Holocene floodbasin; light red brown silty clay loam } \\
\text { with filaments and threads of secondary } \mathrm{CaCO}_{3} \text {. }\end{array}$ \\
\hline $\mathrm{Bk3}$ & $110-150 \mathrm{~cm}$ & $\begin{array}{l}\text { Early or Middle Holocene floodbasin; light beige silty clay loam with } \\
\text { few filaments and threads and few } 1 \mathrm{~cm} \text { diameter segregations of } \\
\text { secondary } \mathrm{CaCO}_{3} \text {. }\end{array}$ \\
\hline $\mathrm{BC}$ & $150-240 \mathrm{~cm}$ & Early or Middle Holocene floodbasin; light beige silty clay loam. \\
\hline $\mathrm{C} 1$ & $240-260 \mathrm{~cm}$ & $\begin{array}{l}\text { Early or Middle Holocene channel; } 70 \% \text { grain-supported and } \\
\text { unconsolidated pea- to golfball-size gravels in a yellowish tan matrix. }\end{array}$ \\
\hline $\mathrm{C} 2$ & $260-280 \mathrm{~cm}$ & Early or Middle Holocene channel; light tan sand. \\
\hline $2 \mathrm{C} 1$ & $280-310 \mathrm{~cm}$ & $\begin{array}{l}\text { Latest Pleistocene or Early Holocene channel; } 80 \% \text { grain-supported } \\
\text { and consolidated pea- to golfball-size gravels in a tan sandy matrix. }\end{array}$ \\
\hline $2 \mathrm{C} 2$ & $310-315 \mathrm{~cm}$ & Latest Pleistocene or Early Holocene channel; light reddish tan sand. \\
\hline $2 \mathrm{C} 3$ & $310-320 \mathrm{~cm}$ & $\begin{array}{l}\text { Latest Pleistocene or Early Holocene channel; } 45 \% \text { grain-supported } \\
\text { and consolidated marble size gravels in a reddish sandy matrix. }\end{array}$ \\
\hline
\end{tabular}




\begin{tabular}{||c|c|c||}
\hline \multicolumn{3}{|c||}{$\begin{array}{c}\text { B18; T1; Late Holocene channel and overbank deposits; 944 feet; } \\
\text { (estimated from log borings of Raba-Kistner 1994). }\end{array}$} \\
\hline Unit I & $310-320 \mathrm{~cm}$ & brown silt (sandy loam) with some organic material. \\
\hline Unit II & $310-320 \mathrm{~cm}$ & brown sandy and gravelly \\
\hline Unit III & $300-343 \mathrm{~cm}$ & tan gravelly and sandy. \\
\hline
\end{tabular}



